\title{
NOŻE Z WCZESNOŚREDNIOWIECZNEGO CMENTARZYSKA W SOWINKACH POD POZNANIEM - ZE STUDIÓW NAD TYPOLOGIĄ I TECHNIKAMI KOWALSKIMI ${ }^{1}$
}

\author{
KNIVES FROM THE EARLY MEDIEVAL GRAVE FIELD \\ IN SOWINKI NEAR POZNAŃ: STUDIES OF TYPOLOGY \\ AND BLACKSMITH'S TECHNIQUES
}

\begin{abstract}
The article presents a typological analysis of a collection of iron knives comprising 70 specimens from the early medieval grave field in Sowinki near Poznań, dated back to the time between the second half of the $10^{\text {th }}$ century and the early $12^{\text {th }}$ century. Sixteen of the specimens were subjected to further metallographic analyses, carried out in the Casting Institute in Krakow. As a result, 4 major technological groups were identified with as many as 10 separate types. In half of the studied knives, the technology of welding iron and steel was used, i.e. steel in the form of an overlay or a "sandwich" in the classical variant. The analysis proved that the knives from the grave field represented the type of metal and technologies typical of the Vistula basin as well as the early medieval Kievan Rus'.
\end{abstract}

Keywords: early medieval grave field, blacksmith's techniques, iron knives made from welded iron and steel, steel overlay, technology in the "sandwich" variant.

\section{UWAGI WSTEPNE}

W opracowaniu przedstawiono analizę typologiczno-metalograficzną noży żelaznych odkrytych na dwufazowym wczesnośredniowiecznym cmentarzysku w Sowinkach k/Poznania datowanym pod względem archeologicznym i metodami przyrodniczymi na okres od 2 połowy X w. po początek XII wieku (Krzyszowski 1992; 1995, 1997; Krzyszowski, Błaszczyk 2016; Michalska, Krzyszowski 2017).

* ORCID: 0000-0003-4042-1064; Muzeum Archeologiczne w Poznaniu, ul. Wodna 27, 61-781 Poznań, e-mail: andrzej.krzyszowski@muzarp.poznan.pl.

${ }^{1}$ Opracowanie dedykuję pamięci Pana Profesora Władysława Łosińskiego i Jego Małżonki w dowód uznania i szacunku oraz naszej wieloletniej współpracy nad materiałami świelubskimi i rozmów nie tylko o archeologii. 
Przedmioty te należą do pospolitych elementów wyposażenia wczesnośredniowiecznych grobów i w tym opracowaniu rozpatrzono je generalnie w dwóch aspektach: w zakresie typologii oraz technik kowalskich, analizując również zagadnienie ich lokalizacji przy pochówku, z uwagi na płeć pochowanej osoby oraz wymiary. Ponadto omówiono poszczególne elementy składowe noży, a więc oprawki do rękojeści, pozostałości skórzanych pochewek oraz metalowe okucia do tych ostatnich. W większości przedmioty te nie mają waloru chronologicznego, a jedynie w kontekście występowania brązowych okuć skórzanych pochewek noży, jak też innych wyrobów towarzyszących - można ustalić bliższą ich chronologię; uwaga ta dotyczy również kolekcji noży z Sowinek.

Noże są podstawowym narzędziem o charakterze wielofunkcyjnym, związanym przede wszystkim z przygotowaniem pożywienia, ale służyły głównie w domowej wytwórczości, w ówczesnych warsztatach rzemieślniczych i zapewne do uboju mniejszych zwierząt, a także jako broń (Piekalski 1991, s. 75). Podobnie jak na wielu innych cmentarzyskach wczesnośredniowiecznych, ale i też na stanowiskach osadowych czy grodowych, w tym również w Sowinkach noże żelazne należą do najliczniejszych i najbardziej pospolitych elementów wyposażenia. Ogółem znaleziono 70 okazów, wszystkie są wykonane z żelaza, w tym 68 noży wystąpiło w 64 grobach, dwa okazy zaś odkryto luźno w warstwie naturalnej (ryc. 1; tabela 1). Jeden $\mathrm{z}$ tych ostatnich noży wystąpił bezpośrednio $\mathrm{w}$ pobliżu jednej z jam grobowych, w odległości zaledwie $10 \mathrm{~cm}$ od granicy jamy grobu $\mathrm{nr} 8$ - można więc $\mathrm{z}$ dużym prawdopodobieństwem założyć, iż pierwotnie mógł on stanowić również wyposażenie pochówka $\mathrm{z}$ tego grobu. $\mathrm{Z}$ kolei $\mathrm{w}$ drugim przypadku nóż wystąpił luźno na arze 12A (w wykopie WI/89), lecz bez wyraźnego związku z pobliskim wczesnośredniowiecznym zespołem grobowym.

Groby, w których występują noże na cmentarzysku w Sowinkach, stanowią 78\% ogółu pochówków z wyposażeniem, natomiast odsetek grobów, gdzie zmarłym towarzyszy wyłącznie nóż, wynosi około $20 \%$ i osiąga podobny odsetek jak na innych wielkopolskich cmentarzyskach z tego okresu, gdzie wskaźnik ten kształtuje się w granicach 17-20\%, np. w Młodzikowie (Leciejewicz, Łosiński 1960) czy w Dziekanowicach, stan. 2 i stan. 22 (Wrzesiński 2000, s. 91). Również zbliżony udział grobów z nożami został zanotowany na kolejnym dużym wczesnośredniowiecznym cmentarzysku w Kałdusie, gdzie osiąga wartość 24,2\% całego zespołu wśród pochówków rozpoznanych (Chudziak, Bojarski, Stawska 2010, s. 83).

W 60 grobach zarejestrowano po jednym egzemplarzu, a jedynie w dwóch grobach zanotowano po dwa noże (groby $\mathrm{nr} 77,148$ i 151) i w jednym przypadku (grób nr 70) znajdowały się aż trzy noże. Zmarli wyposażeni w noże to: dzieci w wieku Infans $I^{2}$ - dwa groby (nr 64, 245), dzieci w wieku Infans II (wzgl.

2 Oznaczenia antropologiczne zmarłych z cmentarzyska w Sowinkach zaczerpnięto wg ustaleń dra Jerzego Kozaka z Instytutu Antropologii Uniwersytetu im. Adama Mickiewicza w Poznaniu (por. Kozak 1996, s. 91-96). 

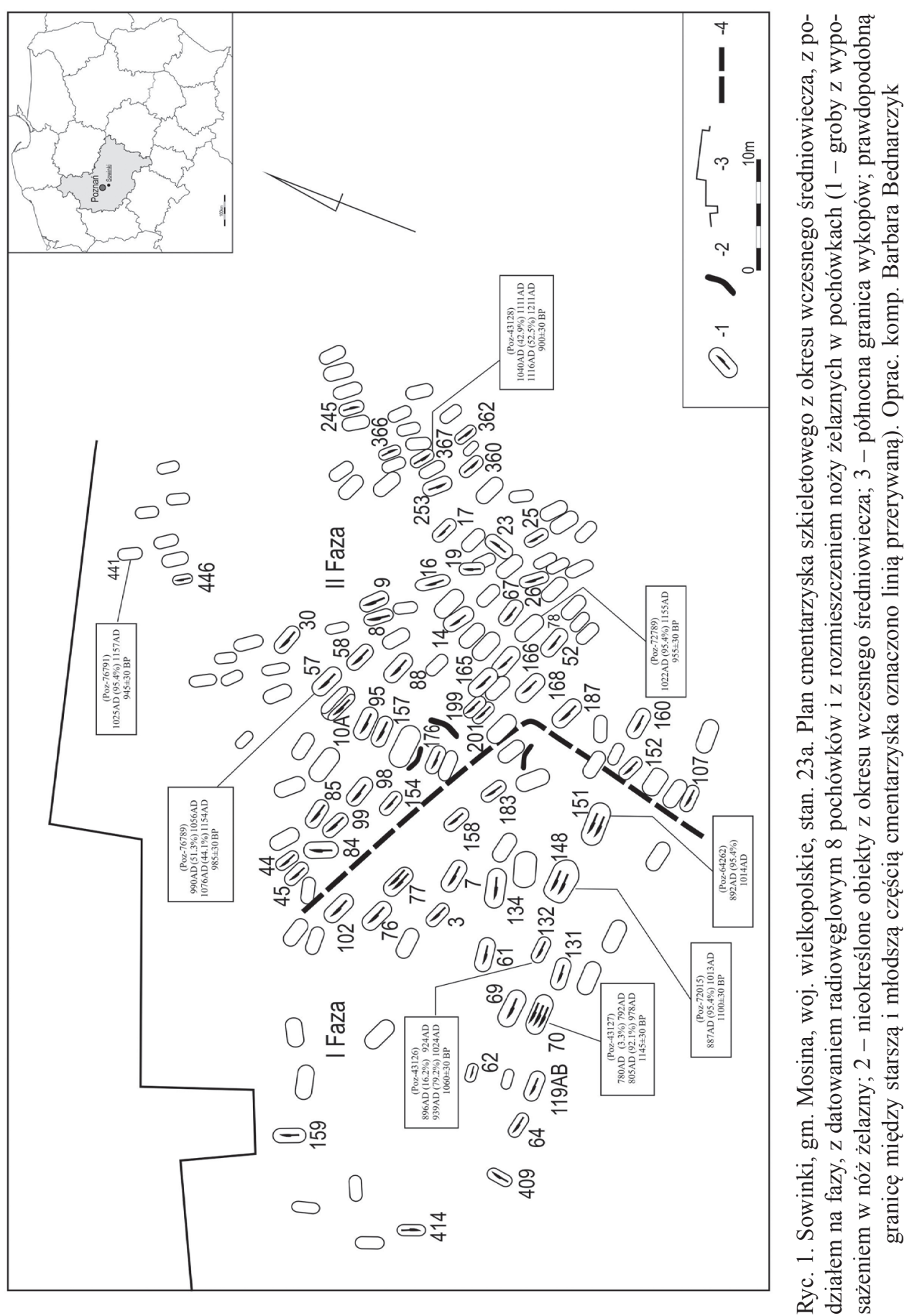


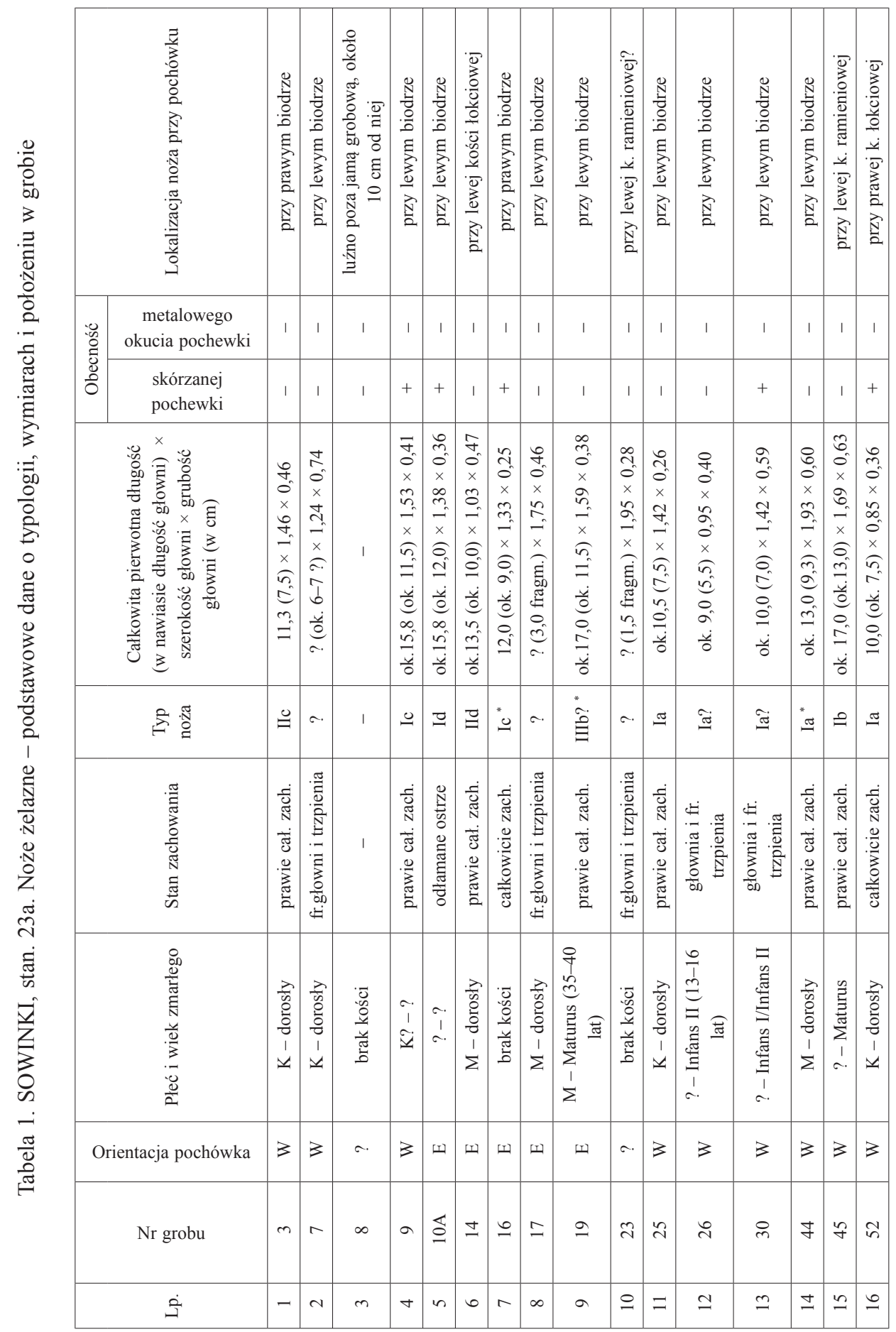




\begin{tabular}{|c|c|c|c|c|c|c|c|c|c|c|c|c|c|c|c|c|c|}
\hline 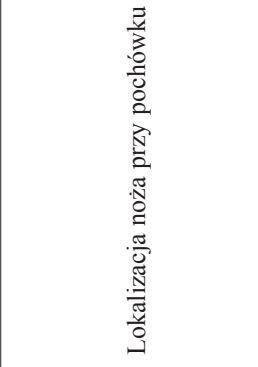 & 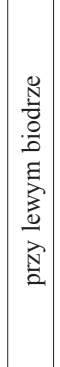 & 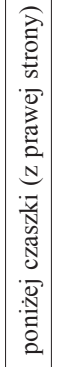 & 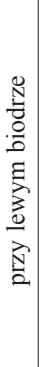 & 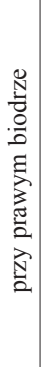 & 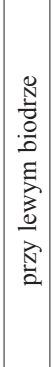 & 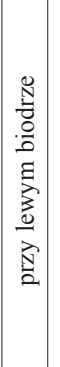 & 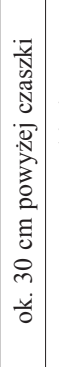 & 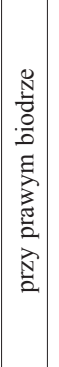 & 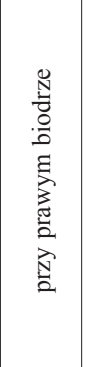 & 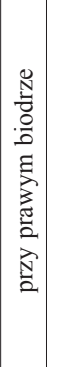 & 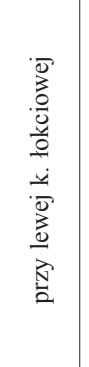 & 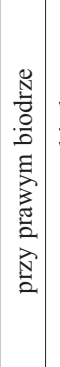 & 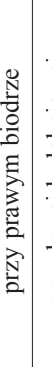 & 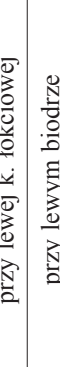 & 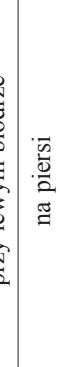 & 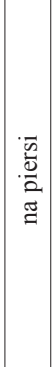 & 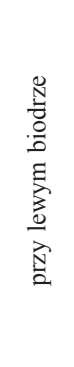 \\
\hline \begin{tabular}{c|c} 
metalowego \\
$:$ & okucia pochewki \\
\hdashline & okcis
\end{tabular} & 1 & 1 & 1 & 1 & 1 & 1 & & + & 1 & 1 & 1 & 1 & & \begin{tabular}{l|l}
1 & 1
\end{tabular} & 1 & 1 & 1 \\
\hline $\begin{array}{l}\text { skórzanej } \\
\text { pochewki }\end{array}$ & + & 1 & 1 & 1 & 1 & 1 & 1 & + & + & 1 & + & + & & $1+$ & + & + & + \\
\hline 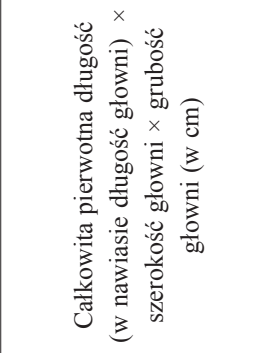 & 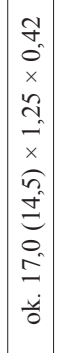 & 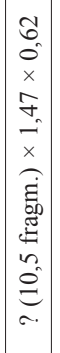 & 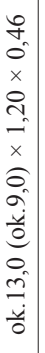 & 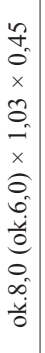 & 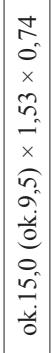 & 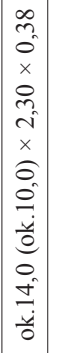 & 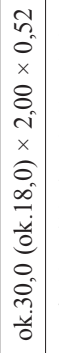 & 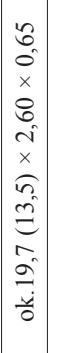 & 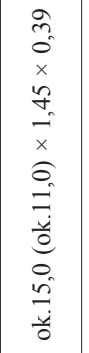 & 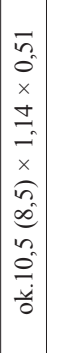 & 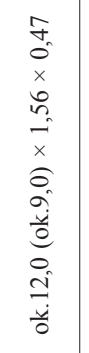 & 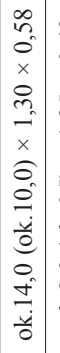 & 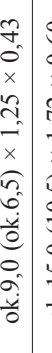 & 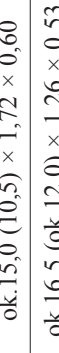 & 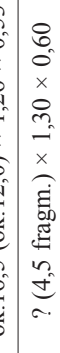 & 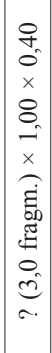 & 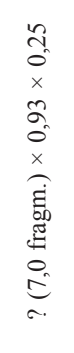 \\
\hline s. & 官 & -. & هـ" & $\therefore$ & $\approx$ & 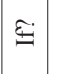 & $\stackrel{*}{z}$ & 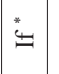 & き & $\approx$ & $\Xi$ & $\approx$ & Ðं & $\approx$ & $\Rightarrow \sigma$. & a. & a. \\
\hline 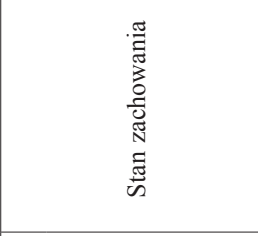 & 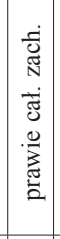 & $\mid \begin{array}{c}\cdot \vec{z} \\
\bar{z} \\
\frac{0}{b 0} \\
\dot{H}\end{array}$ & 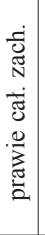 & 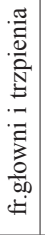 & 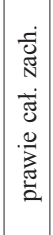 & 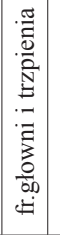 & 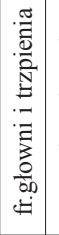 & 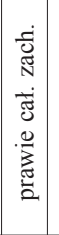 & 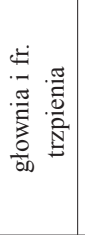 & 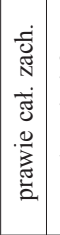 & 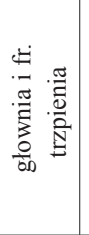 & 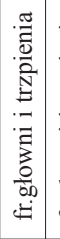 & 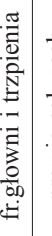 & 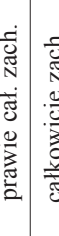 & 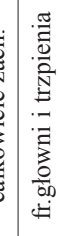 & 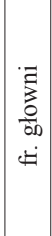 & $\begin{array}{l}\vec{z} \\
\text { 言 } \\
\dot{b 0} \\
\ddot{H}\end{array}$ \\
\hline 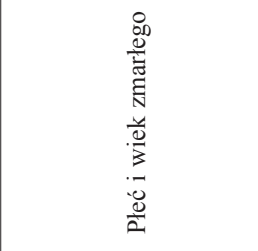 & 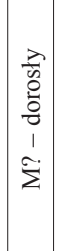 & 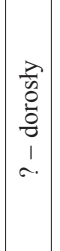 & $\begin{array}{l}\frac{\lambda}{0} \\
0 \\
0 \\
0 \\
1 \\
1 .\end{array}$ & 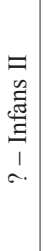 & 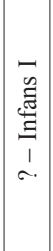 & $\mid \begin{array}{c}a \\
i \\
\grave{z}\end{array}$ & $\mid \begin{array}{l}0 \\
\frac{n}{2} \\
\frac{z}{2} \\
1 \\
\Sigma \\
\Sigma\end{array}$ & 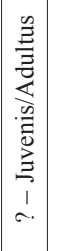 & 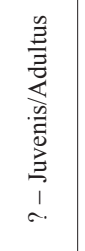 & 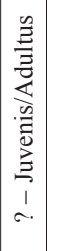 & $\begin{array}{l}\frac{0}{2} \\
\frac{z}{2} \\
\frac{1}{2} \\
\Sigma\end{array}$ & 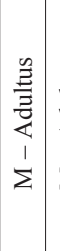 & 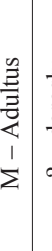 & 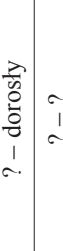 & c. & 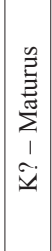 & 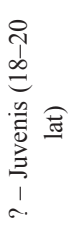 \\
\hline Orientacja pochówka & 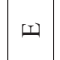 & ш & w & 山 & $\varpi$ & 3 & w & $\Phi$ & 山 & $\omega$ & 山 & w & I & 3 & 3 & $\omega$ & w \\
\hline Nr grobu & in & $\infty$ & 5 & S & t & 5 & 8 & 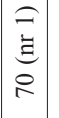 & 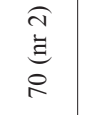 & $\mid \begin{array}{l}0 \\
\stackrel{3}{\Xi} \\
2 \\
2\end{array}$ & 2 & 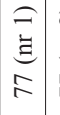 & $\begin{array}{l}\hat{A} \\
\text { 兘 } \\
\text { ह }\end{array}$ & $\begin{array}{l} \pm \\
+\infty\end{array}$ & 0 & 2 & $\infty$ \\
\hline$\dot{3}$ & $=$ & $\stackrel{\infty}{-\infty}$ & 2 & त & $\vec{\sim}$ & $\pi$ & $\pi$ & $\stackrel{\sim}{\sim}$ & 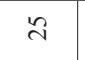 & $\stackrel{\sim}{*}$ & $\bar{\lambda}$ & 永 & ते & $\stackrel{\bar{m}}{\bar{c}}$ & $\approx \approx$ & $m$ & m \\
\hline
\end{tabular}




\begin{tabular}{|c|c|c|c|c|c|c|c|c|c|c|c|c|c|c|c|c|c|c|}
\hline \multicolumn{2}{|c|}{ 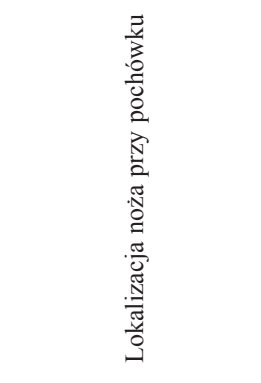 } & 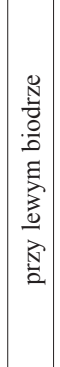 & 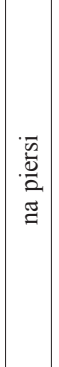 & 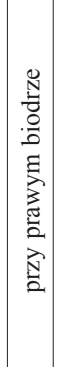 & 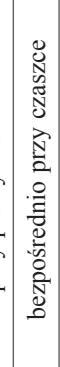 & 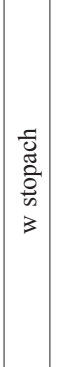 & 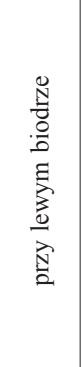 & 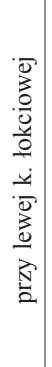 & 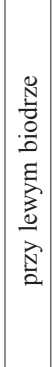 & 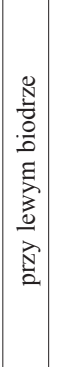 & 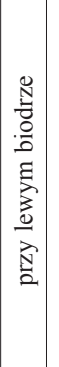 & 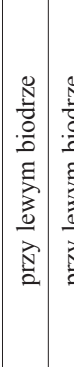 & 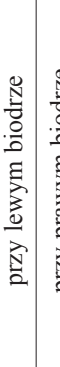 & 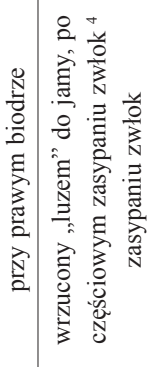 & 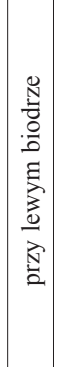 & 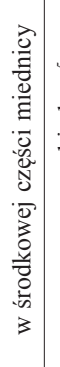 & | & \\
\hline & $\begin{array}{cc} & \text { metalowego } \\
\text { okucia pochewki }\end{array}$ & 1 & 1 & 1 & 1 & 1 & 1 & 1 & 1 & + & + & +9 & $\overrightarrow{+}$ & I & 1 & & & \\
\hline & $\begin{array}{l}\text { skórzanej } \\
\text { pochewki }\end{array}$ & + & + & + & + & + & 1 & + & + & + & + & ++ & + & + & + & + & & + \\
\hline & 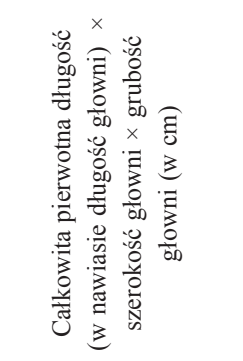 & 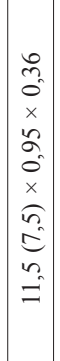 & 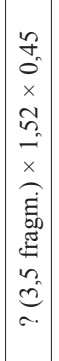 & 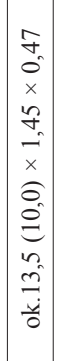 & 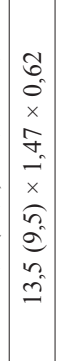 & 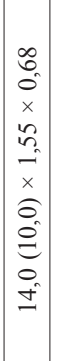 & 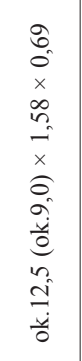 & 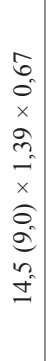 & 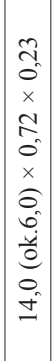 & 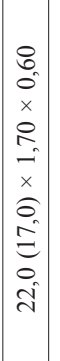 & 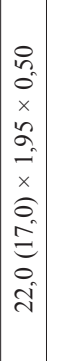 & 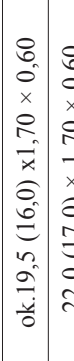 & 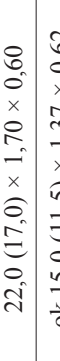 & 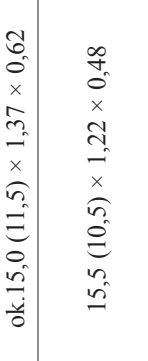 & 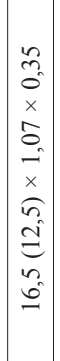 & 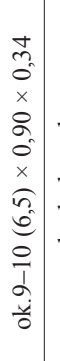 & 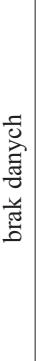 & \\
\hline & 念苋 & $\cong$ & - & $\cong$ & $\approx$ & $\cong$ & 巳ु & $\cong$ & $\approx$ & $\because$ & \pm & $=$ & \pm & $\approx$ & $\cong$ & $\tilde{\Theta}$ & a & $\Xi$ \\
\hline & 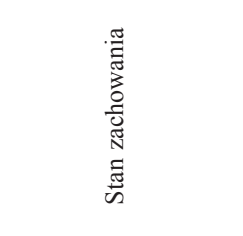 & 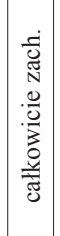 & 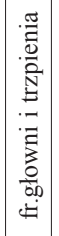 & 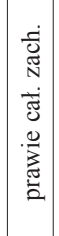 & 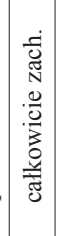 & 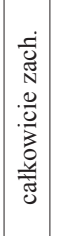 & 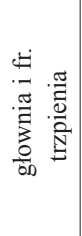 & 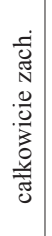 & 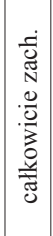 & 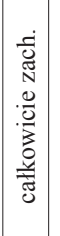 & 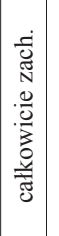 & 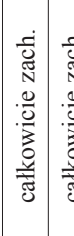 & 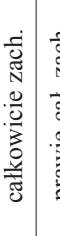 & 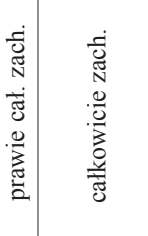 & 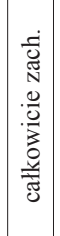 & $\begin{array}{l}\vec{y} \\
\vec{z} \\
\frac{0}{b 0} \\
\ddot{t}\end{array}$ & . & \\
\hline & 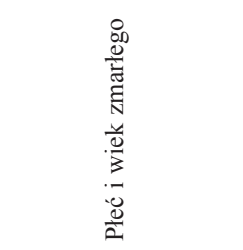 & 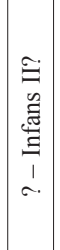 & 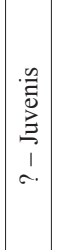 & 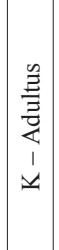 & 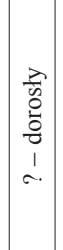 & 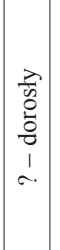 & 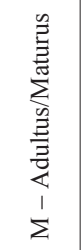 & 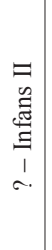 & $\begin{array}{l}\frac{\lambda}{0} \\
0 \\
0 \\
0 \\
1 \\
\Sigma \\
\Sigma\end{array}$ & 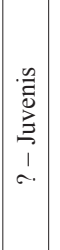 & 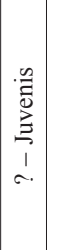 & 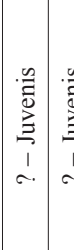 & 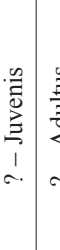 & 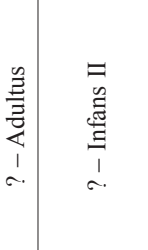 & $\begin{array}{r}i \\
i \\
r .\end{array}$ & 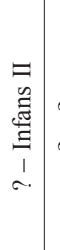 & & \\
\hline & Orientacja pochówka & 四 & 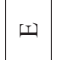 & 四 & $\varpi$ & 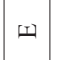 & w & 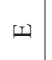 & 3 & $\omega$ & $\omega$ & 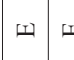 & 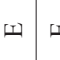 & 3 & 四 & 3 & w & 四 \\
\hline & $\mathrm{Nr}$ grobu & 2 & $\tilde{\Xi}$ & $\stackrel{\circ}{=}$ & $\underset{\Xi}{\leftrightarrows}$ & $\stackrel{m}{\Xi}$ & $\bar{m}$ & $\cong$ & $\ddot{m}$ & 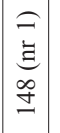 & 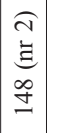 & 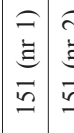 & 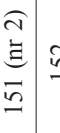 & 苟 & $\hat{n}$ & $\stackrel{\infty}{n}$ & है & $\stackrel{8}{-1}$ \\
\hline & $\dot{3}$ & $\dddot{m}$ & i & $\hat{n}$ & 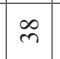 & mे & q & $F$ & F & $q$ & J & \begin{tabular}{l|l}
$f$ & 5
\end{tabular} & 87 & $\stackrel{\infty}{q}$ & q & in: & $\vec{n}$ & in \\
\hline
\end{tabular}




\begin{tabular}{|c|c|c|c|c|c|c|c|c|c|c|c|c|c|c|c|c|}
\hline 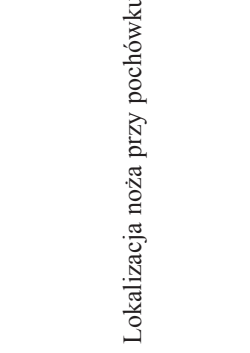 & 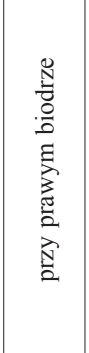 & 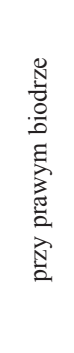 & 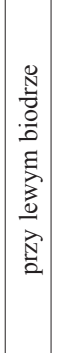 & 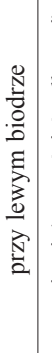 & 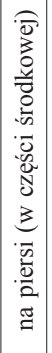 & 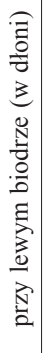 & 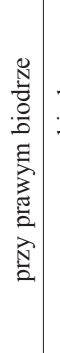 & 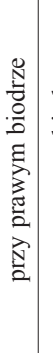 & 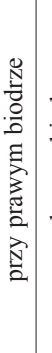 & 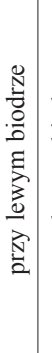 & 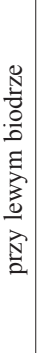 & 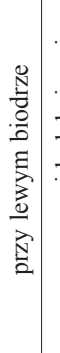 & 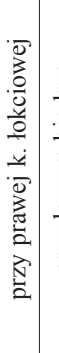 & 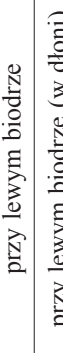 & 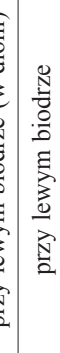 & 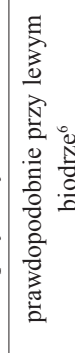 \\
\hline 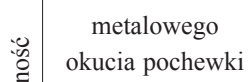 & + & 1 & 1 & + & 1 & 1 & 1 & 1 & 1 & 1 & 1 & 1 & 1 & \begin{tabular}{l|l}
1 & 1 \\
1
\end{tabular} & + & 1 \\
\hline $\begin{array}{l}\text { skórzanej } \\
\text { pochewki }\end{array}$ & + & 1 & + & + & + & + & + & + & 1 & 1 & 1 & 1 & & \begin{tabular}{l|l}
1 & 1 \\
1
\end{tabular} & + & 1 \\
\hline 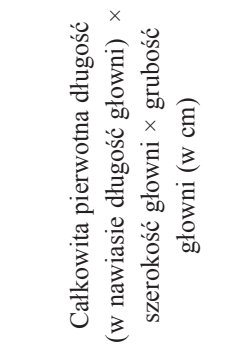 & 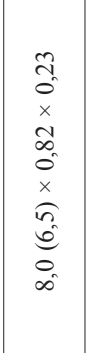 & 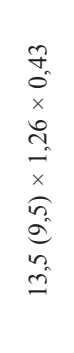 & 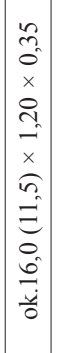 & 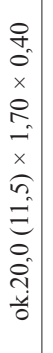 & 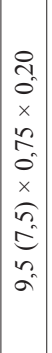 & 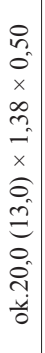 & 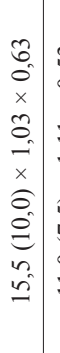 & $\begin{array}{l}\hat{n} \\
0 \\
x \\
x \\
= \\
\dot{x} \\
5 \\
n \\
0 \\
0 \\
=\end{array}$ & $\begin{array}{c}0 \\
0 \\
0 \\
x \\
b \\
+ \\
-1 \\
x \\
0 \\
0 \\
0 \\
0 \\
0 \\
0 \\
0\end{array}$ & 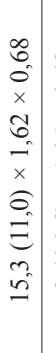 & 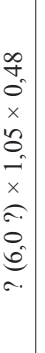 & 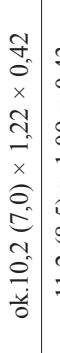 & 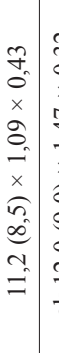 & 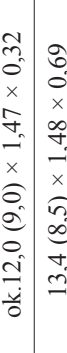 & 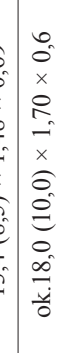 & 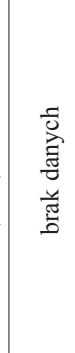 \\
\hline 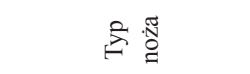 & $\Xi$ & "త & $\cong$ & $\Xi$ & $\approx$ & $\approx$ & $\approx$. & $\Xi$ & פ & 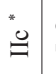 & تृ & " & "ש & 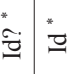 & $\tilde{\sigma}$ & r. \\
\hline 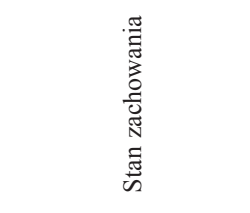 & 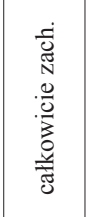 & 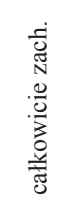 & 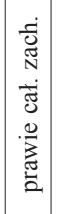 & 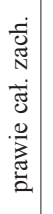 & 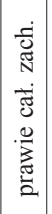 & 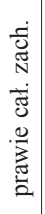 & 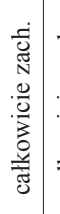 & 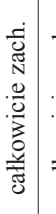 & 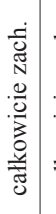 & 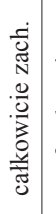 & 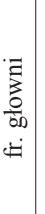 & 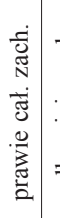 & 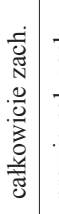 & 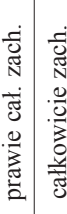 & 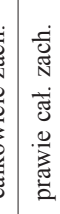 & 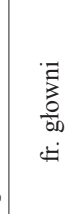 \\
\hline 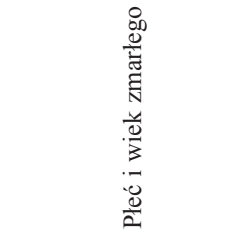 & 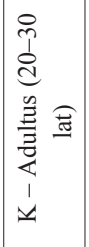 & 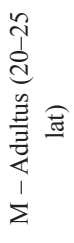 & $\mid \begin{array}{l}\frac{n}{z} \\
\frac{z}{z} \\
\frac{z}{L} \\
1 \\
\Sigma\end{array}$ & 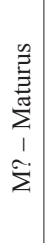 & $\mid \begin{array}{c}\frac{3}{0} \\
\frac{0}{0} \\
0 \\
\frac{0}{0} \\
1 \\
1 \\
\sigma .\end{array}$ & $\begin{array}{l}\frac{n}{2} \\
\frac{E}{z} \\
\frac{\pi}{4} \\
1 \\
\Sigma\end{array}$ & 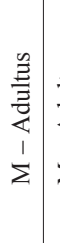 & $\begin{array}{l}\frac{0}{E} \\
\frac{z}{2} \\
1 \\
\Sigma\end{array}$ & 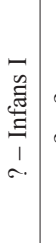 & i & 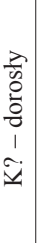 & 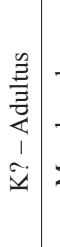 & $\begin{array}{l}\frac{\lambda}{0} \\
0 \\
0 \\
0 \\
1 \\
\Sigma\end{array}$ & 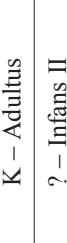 & 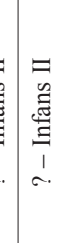 & i. \\
\hline Orientacja pochówka & 3 & $m$ & (1) & 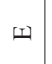 & 3 & 山 & w & 山) & 3 & 3 & 3 & 3 & 3 & 3 in & $z$ & 3 \\
\hline $\mathrm{Nr}$ grobu & $\stackrel{2}{6}$ & $\stackrel{\bullet}{\circ}$ & $\stackrel{\infty}{0}$ & $\stackrel{\circ}{\Xi}$ & $\ddot{\mathscr{O}}$ & $\stackrel{\infty}{\infty}$ & बे & $\overrightarrow{\mathrm{i}}$ & 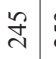 & $\stackrel{\overbrace ֶ}{\sim}$ & : & ర్ల & : & 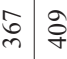 & $\vec{\gamma}$ & fo \\
\hline$\dot{3}$ & $n$ & in & $i n$ & in & in & $\infty$ & in & 8 & $\vec{\sigma}$ & $\mathcal{S}$ & 8 & d & 8 & $\triangle \square$ & $\infty$ & 8 \\
\hline
\end{tabular}




\begin{tabular}{|c|c|c|}
\hline \multicolumn{2}{|c|}{ 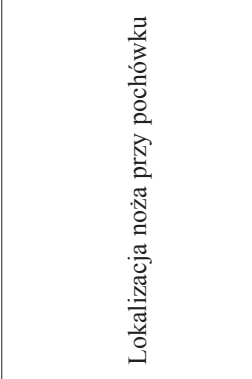 } & 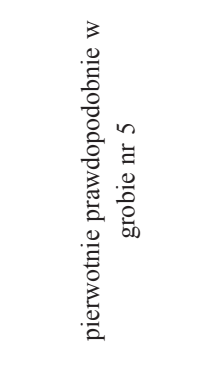 \\
\hline \multirow{2}{*}{$\begin{array}{l}\text { i. } \\
\text { o } \\
0 \\
0 \\
0 \\
0 \\
0\end{array}$} & $\begin{array}{c}\text { metalowego } \\
\text { okucia pochewki }\end{array}$ & 1 \\
\hline & $\begin{array}{l}\text { skórzanej } \\
\text { pochewki }\end{array}$ & 1 \\
\hline \multicolumn{2}{|r|}{ 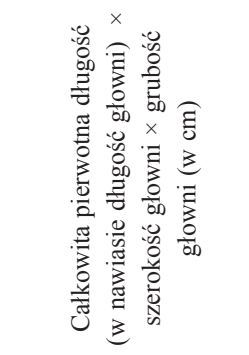 } & 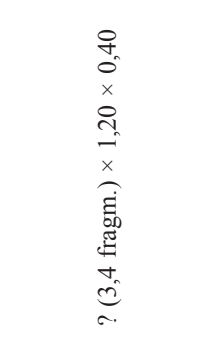 \\
\hline & 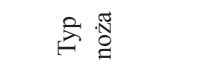 & a. \\
\hline & 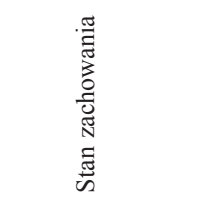 & 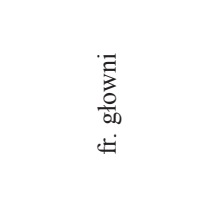 \\
\hline & 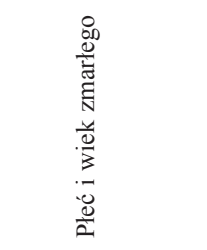 & 1 \\
\hline & ientacja pochówka & w wykopie WI/89 \\
\hline & $\mathrm{Nr}$ grobu & 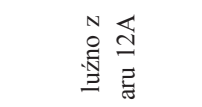 \\
\hline & $\dot{\Delta}$ & 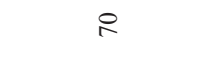 \\
\hline
\end{tabular}

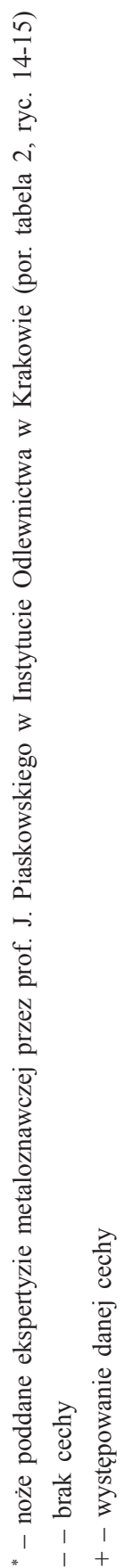


Infans I/Infans II) - dziewięć grobów (nr 26, 30, 62, 99, 132, 154, 158, 409, 414), kolejno osoby młodociane (Juvenis), lecz bez określenia płci - pięć grobów (nr 98, 102, 148, 151, 160), następnie kobiety - 11 grobów (nr 3, 7, 9, 25, 52, 95, 107, 165, 360, 362, 367) i mężczyźni - 18 grobów (nr 14, 17, 19, 44, 57, 67, 69, 76, 77, 131, 134, 166, 168, 176, 187, 199, 201, 366). Z kolei w 21 grobach zmarłych w wieku Adultus lub Maturus nie oznaczono pod względem płci, choć wydaje się, że na podstawie wyposażenia $\mathrm{w}$ inne zabytki dalszych pięć grobów można by zakwalifikować do pochówków męskich (groby nr 16, 70, 85, 148 i 151) i kolejne dwa - do pochówków kobiecych (groby nr 119A i 119B). Widać więc, że noże nie określają zdecydowanie płci zmarłego, choć częściej w Sowinkach są jednak notowane w pochówkach męskich (co stanowi 35,9\% pośród tego rodzaju grobów), kolejno w grobach nieoznaczonych pod względem płci (25\%), a następnie w jednakowym stopniu w pochówkach kobiecych i dziecięcych (po 17,2\%) i w końcu w pochówkach typu Juvenis (zaledwie 4,7\%).

Spośród odkrytych grobów wyposażonych w nóż większość (39 grobów) była zorientowana głową na wschód, z tego 15 - to pochówki mężczyzn, a tylko dwa to pochówki kobiet, pozostałe reprezentują pochówki zmarłych dzieci (4 groby), młodocianych (5 grobów) lub dorosłych (7 grobów), ale nieokreślonych pod względem płci, względnie nieokreślonych pod względem płci i również wieku (łącznie 3 groby). $\mathrm{Z}$ kolei pochówki wyposażone w nóż, lecz zorientowane głową na zachód, stanowią 24 groby, pośród których większość tym razem reprezentuje kobiety (9 grobów), rzadziej mężczyzn (4 groby) i jeszcze rzadziej dzieci (4 groby), pozostałe pochówki w tej kategorii pozostają nieokreślone pod względem płci bądź wieku (łącznie 7 grobów). W końcu jedynie trzy pochówki z nożami w wyposażeniu były zorientowane na $\mathrm{S}$ i N (oba określono jako Infans II) i na SE (pochówek nieokreślony zarówno pod względem płci, jak i wieku).

Noże leżały najczęściej w okolicach pasa, przy lewym (33 przypadki w 31 grobach: $\mathrm{nr} 7,9,10 \mathrm{~A}, 17,19,25,26,30,44,57,61,64,67,85,98,99,131,134$, $148(\times 2), 151(\times 2), 157,168,176,187,253,360,362,367,409,414,446)$ lub przy prawym biodrze (17 przypadków w 14 grobach: nr 3, 16, 62, $70(\times 3)$, $77(\times 2), 107,152,159,160,165,166,199,201,245)$ względnie wyjątkowo w środkowej części biodra (grób nr 158), następnie powyżej lewego lub prawego łokcia (6 przypadków; groby $\mathrm{nr} 14,52,76,84,132,366)$ względnie ramienia (2 przypadki; groby $\mathrm{nr} 23,45)$, i w okolicy kręgosłupa, na wysokości piersi (w 4 grobach $\mathrm{nr} 88,95,102,183$ ); w tym ostatnim przypadku tylko jeden pochówek (z grobu nr 95) należał do kobiety, pozostałe należały do osób zmarłych w wieku Juvenis lub Adultus, lecz nieokreślonych pod względem płci. Ponadto w pojedynczych przypadkach zanotowano występowanie noży nad (grób nr 69) lub bezpośrednio przy czaszce (groby nr 58 i 119A), bądź w okolicy stóp (grób nr 119B). Natomiast w jeszcze jednym przypadku nóż został do jamy grobowej „wrzucony luzem”, zapewne już po częściowym przysypaniu zwłok ziemią (w grobie $\mathrm{nr}$ 154). Z powyższego przeglądu wynika więc, że noże zalegały najczęściej 
przy lewej stronie zmarłych, przy biodrze, rzadziej leżały na piersi - co prawdopodobnie odzwierciedla ówczesny sposób ich noszenia. W pierwszym przypadku noże były noszone niewątpliwie na wysokości pasa, gdzie spoczywały zapewne zawieszone w skórzanej pochewce, $\mathrm{w}$ drugim zaś przypadku występowanie noży w okolicach klatki piersiowej świadczy, iż były one najprawdopodobniej zawieszone na piersi.

Część noży z Sowinek jest źle zachowana i nie nadaje się do szczegółowej analizy, odnotowano 13 takich przypadków (z grobów nr 7, 8, 17, 23, 58, 62, 88, $95,98,102,159,446$ i luźno z w-wy na arze 12A w wykopie WI/89), u kolejnych 11 okazów noży (z grobów nr 19, 26, 30, 57, 67, 69, 76, 77 [× 2], 158, 360) zanotowano $\mathrm{z}$ kolei brak jednej z jego części, i choć ich typologię można było ustalić, to jednak z dużym prawdopodobieństwem. Lepiej zachowane egzemplarze wykazują pewne różnice w długości, w ukształtowaniu grzbietu głowni (tylca) i trzpienia, jak też w ukształtowaniu przejścia głowni w trzpień. Głownie wszystkich odkrytych noży są jednościenne, a z kolei trzpienie rękojeści oprawiano z reguły w drewno lub rzadziej inny materiał organiczny (o czym szczegółowiej w rozdziale poniżej).

Noże występujące w grobach mężczyzn osiągały różną długość: dla 19 okazów wymiar ten wynosił od 9,0 cm do $30,0 \mathrm{~cm}$, ze średnią $15,2 \mathrm{~cm}$, natomiast uwzględniając dalsze pięć grobów (nr 16, 70, 85, 148 i 151), które metodami archeologicznymi określono jako prawdopodobnie również męskie - średnia ta wzrasta do $16,0 \mathrm{~cm}$. Uwzględniając więc dodatkowo dziewięć noży z tej ostatniej grupy grobów, okazuje się, że najliczniejsze w grobach męskich są noże o długości między 9 a $15 \mathrm{~cm}$, których jest 15 okazów, nie mniej liczne są też noże o długości powyżej $15 \mathrm{~cm}$ - których łącznie wydzielono 13, przy czym dwa z nich osiągały wielkość między 15 a $16 \mathrm{~cm}$, trzy następne mierzyły po około $17 \mathrm{~cm}$, siedem miało długość między $20-22 \mathrm{~cm}$ i jeden mierzył aż $30 \mathrm{~cm}$. Z kolei pośród grobów kobiet w 11 grobach wystąpiło po jednym nożu, których długość wahała się między 8 a prawie $16 \mathrm{~cm}$, ze średnią wynoszącą $9,1 \mathrm{~cm}$. Najczęściej w grobach kobiecych były notowane noże o długości między $10 \mathrm{~cm}$ a $13,5 \mathrm{~cm}$ (6 okazów), a tylko wyjątkowo jeden nóż z grobu nr 9 mierzył $15,8 \mathrm{~cm}$. W 11 grobach dzieci wystąpiło z kolei 11 noży, których rozpiętość długości zawiera się między $9 \mathrm{~cm}$ a $18 \mathrm{~cm}$, ze średnią $12,7 \mathrm{~cm}$, a najliczniejszą grupą wielkościową noży notowaną w tych grobach są okazy mierzące między $9 \mathrm{~cm}$ a $11,5 \mathrm{~cm}$ (5 sztuk). I w końcu w pięciu grobach zmarłych w wieku Juvenis (bez określenia płci) spośród pięciu noży wystąpił tylko jeden okaz nieuszkodzony, który mierzył $14 \mathrm{~cm}$ (z grobu nr 160). Potwierdzeniem przytoczonych różnic $w$ wielkości noży w zależności od płci są kolejne dokonane pomiary w zakresie długości jedynie samej głowni noży. I tak w pochówkach męskich (uwzględniając dodatkowe pięć pochówków prawdopodobnie również męskich) wymiar ten kształtował się w granicach od $6 \mathrm{~cm}$ do $17 \mathrm{~cm}$, ze średnią $11,3 \mathrm{~cm}$ (bez uwzględnienia zaś owych pięciu pochówków średnia ta wynosi $10,3 \mathrm{~cm})$. Z kolei w pochówkach kobiecych rozmiar głowni waha się od 
$6 \mathrm{~cm}$ do 11,5 cm, przy średniej $8,1 \mathrm{~cm}$, i w końcu w pochówkach dziecięcych głownie osiągały rozmiar od $5,5 \mathrm{~cm}$ do $10,5 \mathrm{~cm}$, ale ze średnią minimalnie wyższą aniżeli w grobach kobiecych, wyraża je bowiem cyfra $8,2 \mathrm{~cm}$.

Pod względem wyposażenia pośród 64 grobów, gdzie zarejestrowano żelazny nóż, względnie zestaw dwóch lub trzech noży - w 27 grobach (nr 8, 14, 17, 19, $45,57,58,62,64,67,77,84,88,102,107,152,159,160,166,168,183,199$, 201, 245, 253, 260,366) nóż wystąpił jako jedyny element wyposażenia, w kolejnych dziewięciu grobach (nr 9, 25, 52, 95, 98, 154, 158, 362, 367) - oprócz noża wystąpił jeszcze tylko kabłączek skroniowy, w dwóch kolejnych grobach oprócz noża i kabłączka zarejestrowano jeszcze inny zabytek, którym było wiadro klepkowe (grób $\mathrm{nr} 7$ ), i wisiorek dzwoneczkowaty (grób nr 165). I w końcu w 22 kolejnych grobach zarejestrowano żelazny nóż bądź inny zabytek (ale bez kabłączka skroniowego), a były to najczęściej wiaderka klepkowe i naczynia gliniane (groby nr 10A, 23?, 44, 61, 70, 76, 148, 151, 157, 176), osełki kamienne (groby nr 16, 70, 85, 99, 148), paciorki szklane lub z kamieni półszlachetnych (groby nr 30,119A, 119B, 134) oraz w pojedynczych przypadkach żelazny topór (grób nr 69), krzesiwo (grób nr 131), grot do strzały (grób nr 132), brązowy pierścionek (grób nr 26) czy w końcu moneta (grób nr 187).

W tej ostatniej kwestii warto jeszcze zwrócić uwagę na zależność we wczesnośredniowiecznych pochówkach między występowaniem żelaznych noży a płcią i wiekiem zmarlych. W Sowinkach - na podstawie wyżej zaprezentowanych danych - podobnie jak na cmentarzyskach śląskich (Wachowski 1975, s. 38-39, tabela 11) czy małopolskich (Zoll-Adamikowa 1971, s. 67) żelazne noże są częściej notowane w pochówkach męskich $(35,9 \%)$ aniżeli kobiecych $(17,2 \%)$. Odpowiednio na Śląsku odsetek ten jest zbliżony, jak w Sowinkach, i wynosi w pochówkach męskich 35\%, wobec $15,1 \%$ w grobach kobiecych (Wachowski 1975, s. 38-39, tabela 11), z kolei w Małopolsce proporcje te są też analogiczne i przedstawiają się następująco: $33,9 \%$ w grobach męskich i 20,4\% w grobach kobiecych (Zoll-Adamikowa 1971, s. 67). Bywają jednak też cmentarzyska, gdzie te proporcje są odwrotne, jak np. na cmentarzysku w Zgłowiączce na Kujawach, gdzie udział grobów kobiecych z nożami jest większy w stosunku do grobów męskich (Andrzejewska 1996, s. 103).

Podobnie przedstawia się sytuacja w zakresie lokalizacji noży. Uwzględniając wszystkie pochówki na Dolnym Śląsku, K. Wachowski (1975, s. 39) stwierdził, że lewa strona zmarłego była dwukrotnie bardziej uprzywilejowana aniżeli prawa. Także i w tym regionie zanotowano kilkukrotne występowanie wespół noża i wiaderka klepkowego, podobnie jak to miało miejsce w Sowinkach. Podobne wnioski w zakresie zalegania noży, tj. zalegania zazwyczaj przy lewej stronie zmarłego, osiągnięto na wielu innych wczesnośredniowiecznych cmentarzyskach wielkopolskich (Rajewski 1937; Leciejewicz, Łosiński 1960, s. 159; Wrzesiński 2000, s. 92, 102, 106, 108-109), pomorskich (Wojtasik 1968, s. 193-194; Malinowska-Łazarczyk 1982, s. 28), kujawskich (Kaszewscy 1971, s. 388; Chudziak, Bojarski, Stawska 2010, s. 83) czy mazowiecko-podlaskich (Rauhut 1971, s. 466-470). 


\section{TYPOLOGIA}

Na podstawie zbioru sowinieckiego przeprowadzono ich klasyfikację 60 egzemplarzy, których stan zachowania pozwalał na określenie (lub z dużym prawdopodobieństwem) pełnego kształtu i wymiarów narzędzia. Jednak w wielu przypadkach, gdzie zachowały się tylko fragmenty głowni (5 egzemplarzy) bądź fragmenty trzpieni (1 okaz), względnie fragmenty przejścia głowni w trzpień (to kolejne 4 okazy) - klasyfikacja tych okazów była niemożliwa, natomiast u wielu innych, gdzie odnotowano z kolei tylko niewielki brak ostrza bądź trzpienia - klasyfikacja była możliwa (prawdopodobna) do przeprowadzenia (dla 29 noży). Rejestr okazów całkowicie zachowanych liczy w zbiorze sowinieckim 27 egzemplarzy, natomiast liczba okazów tylko nieznacznie zniszczonych, ale z możliwym ustaleniem typologii wynosi 33 noże; łącznie więc rejestr okazów poddanych klasyfikacji typologicznej zawiera 60 noży.

Do typologii okazów całych i niektórych fragmentów noży z Sowinek wykorzystano przede wszystkim schemat typologiczny zaproponowany przez R. Rogosza (typy I-III; Rogosz 1983, s. 264-265, ryc. 224), który następnie rozszerzył J. Wrzesiński (typy IV-VII; Wrzesiński 2000, s. 91n.). Typologia noży z cmentarzyska w Sowinkach przedstawia się zatem następująco:

(a) typ I wg klasyfikacji R. Rogosza grupuje noże na ogół z wąską głownią, prostym tylcem, ostrzem lekko łukowatym oraz z jedno- lub dwustronnie wyodrębnionym trzpieniem - łącznie w Sowinkach wyróżniono 50 egzemplarzy noży tego typu. W zależności od sposobu wyodrębnienia trzpienia wyróżniono dodatkowe odmiany, pośród których najliczniejsza jest odmiana Ia - o trzpieniu wyodrębnionym dwustronnie, która jest reprezentowana przez 37 egzemplarzy (z grobów $\mathrm{nr} 10 \mathrm{~A}$, $25,44,52,61,64,70,76,77$ (x 2), 84, 85, 99, 107, 119A, 119B, 132, 152, 154, $157,160,165,166,168,176,183,187,199,201,245,362,366,414$ - ryc. 2:1, $4-7 ; 3: 1-6 ; 4: 1-6 ; 5: 1-6 ; 6: 1-2,4-9 ; 10: 1-2,4 ; 13: 3 ; 14: 1,4)$, w tym cztery egzemplarze, które z dużym prawdopodobieństwem można także zaliczyć do tej odmiany (z grobów nr 26, 30, 158, 360 - ryc. 2:2-3; 5:4; 6:3). Pozostałe odmiany typu I są reprezentowane mniej licznie, które stanowią: odmiana $\mathrm{Ib}-\mathrm{z}$ trzpieniem wyodrębnionym jednostronnie i łagodnie od strony tylca, która liczy dwa noże (z grobów nr 45 i 134 - ryc. 7:1-2), odmiana Ic - z trzpieniem wyodrębnionym jednostronnie i ostro także od strony tylca - również z dwoma okazami (z grobów nr 9 i 16 ryc. 7:3-4), odmiana Id - o dość krótkiej głowni, z trzpieniem wyodrębnionym dwustronnie, z trzema egzemplarzami (z grobów nr 131, 367 i 409 - ryc. 7:5-7) i w końcu odmiana If - o dość długiej i nieco szerszej głowni, z trzpieniem wyodrębnionym także dwustronnie, która liczy sześć noży (z grobów nr 67, 70, 148 i 151 - ryc. $8: 1-2 ; 11: 1-2 ; 12: 1-2 ; 14: 2-3)$. Pięć noży tej ostatniej odmiany wystąpiło w trzech grobach $(\mathrm{nr} 70,148,151)$ ewidentnie najbogatszych na cmentarzysku;

(b) typ II wg klasyfikacji R. Rogosza - to z kolei noże z podobnie ukształtowaną głownią, jak u typu I, ale od strony tylca, przy sztychu występuje charakte- 


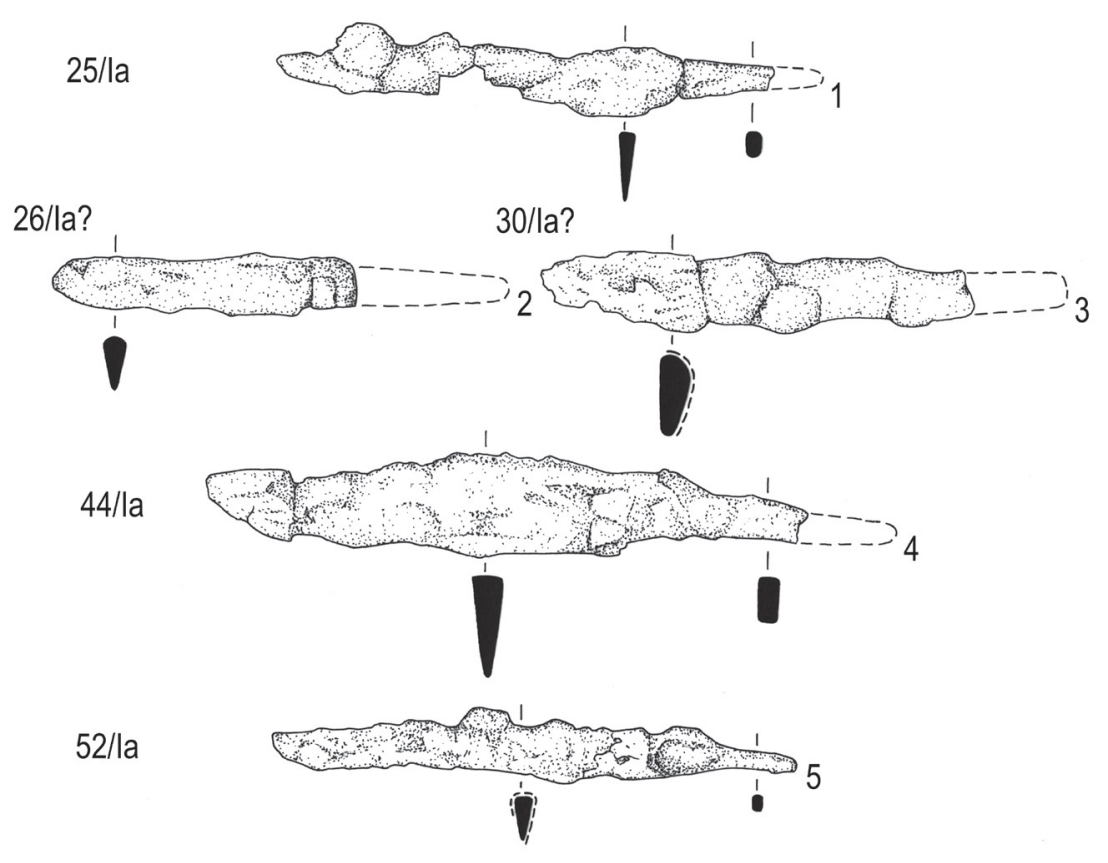

$61 / 1 \mathrm{a}$

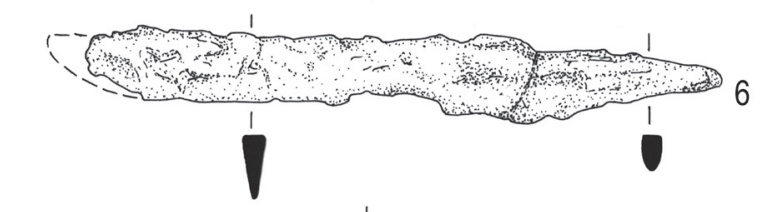

$64 / 1 a$
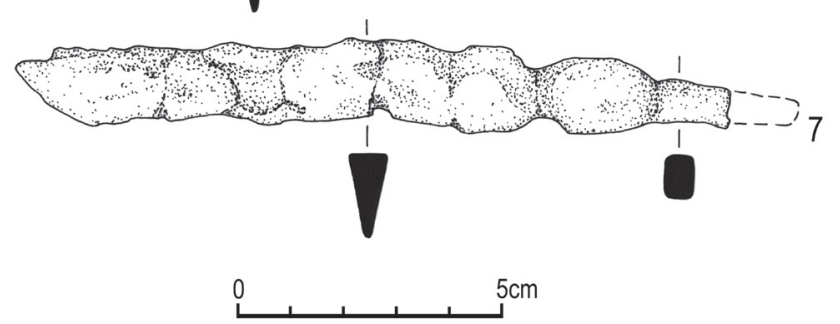

Ryc. 2. Noże żelazne typu Ia wg R. Rogosza (1983) z grobów nr: 25 (1), 26 (2), 30 (3), 44 (4), 52 (5), 61 (6) i 64 (7) (z lewej strony rysunku noża oznaczono: nr grobu i typ wg typologii R. Rogosza 1983 lub J. Wrzesińskiego 2000, natomiast linią przerywaną obecną nad przekrojem noża zaznaczono obecność skórzanej pochewki). Rys. Wiktor Kudra i Jolenta Kędelska, oprac. komp. Jolenta Kędelska 
rystyczne skośne ścięcie, wykształcone niekiedy jako ostrze; łącznie wyróżniono cztery egzemplarze tego rodzaju. Wyróżnione odmiany a-d u tego typu noży umożliwiły $\mathrm{w}$ analizowanym zbiorze na wydzielenie trzech odmian różniących się ukształtowaniem powyższego wycięcia oraz sposobem wyodrębnienia trzpienia. Pierwszą odmianę reprezentuje odmiana IIb $-\mathrm{z}$ ostro wyodrębnionym ostrzem od strony tylca reprezentuje pojedynczy okaz noża z grobu $\mathrm{nr} 70$ (ryc. 8:3), gdzie wystąpiły łącznie trzy noże, i co charakterystyczne - wszystkie odrębnych odmian. Drugą odmianę stanowią okazy typu IIc - o prawie identycznych cechach jak u poprzedniej odmiany, ale tutaj charakterystyczne wycięcie w partii tylcowej głowni ma przebieg łagodny, a nie ostry jak poprzednio - zakwalifikowano tutaj dwa okazy z grobów nr 3 i 253 (ryc. 8:4-5). W końcu ostatnią odmianę IId - stanowi pojedynczy okaz z grobu nr 14 (ryc. 8:6), który posiada również łagodne wycięcie od strony tylca głowni, ale trzpień jest wyodrębniony jednostronnie (od strony tylcowej);

(c) typ III wg klasyfikacji R. Rogosza to noże o ostro zakończonej głowni w formie trójkątnie zbiegającego się ostrza; wyróżniono zaledwie dwa okazy tego typu noży (z grobów nr 19 i 57 - ryc. 8:7-8), które reprezentują w obu przypadkach najprawdopodobniej odmianę IIIb, z regularnym i równomiernym przebiegiem linii grzbietowej i ostrza oraz trzpieniem wyodrębnionym dwustronnie;

(d) ostatnim typem noży wydzielonym w analizowanym zbiorze $\mathrm{z}$ Sowinek jest nóż prawdopodobnie typu IIa wg klasyfikacji R. Rogosza lub typu IV wg klasyfikacji J. Wrzesińskiego (2000, s. 99, ryc. 3). Reprezentuje go pojedynczy egzemplarz z grobu nr 69 (ryc. 13:4-5), który niestety jest w znacznym stopniu skorodowany, co utrudniło właściwą klasyfikację. Charakteryzuje się on najdłuższą głownią pośród wszystkich noży z Sowinek i cechuje się lekko falistym grzbietem oraz ostro zakończonym sztychem, który dodatkowo jest podkreślony poprzez lekko łukowate opuszczenie grzbietu-tylca; z kolei trzpień noża był jednostronnie wyodrębniony i miał kształt prostokątnej sztabki, dodatkowo oprawionej w bogato zdobioną rękojeść wykonaną z okładzin kościanych z poroża. Ten ostatni typ noża - z uwagi na ponadprzeciętne wymiary, przy całkowitej długości około $30 \mathrm{~cm}$ i długości samej głowni wynoszącej około $18 \mathrm{~cm}$ - zakwalifikowano do noży bojowych, który zalegał powyżej czaszki zmarłego w wieku maturus mężczyzny.

Zanalizowane noże nie odbiegają formą od okazów znajdowanych na innych obiektach wczesnośredniowiecznych (Rajewski 1937, s. 69-70; Leciejewicz, Łosiński 1960, s. 159; Wachowski 1975, s. 38-40; Zoll-Adamikowa 1971, s. 64-68; Rogosz 1983, s. 264-265; Wrzesiński 2000, s. 99-100). Wyjątkiem w tym zakresie jest wyżej wspomniany nóż z grobu nr 69 oraz po dwie pary noży znalezionych w dwóch grobach komorowych nr 148 i 151. Te ostatnie (podobnie jak nóż z grobu nr 69), w stosunku do noży odkrytych w innych pochówkach wyróżniały się od pospolitych noży zdecydowanie większą długością wynoszącą około $22 \mathrm{~cm}$ i równie dłuższą głownią liczącą około $16-17 \mathrm{~cm}$. Były to wyroby zdecydowanie bardziej ekskluzywne aniżeli na ogół standardowe okazy znalezione przy innych 


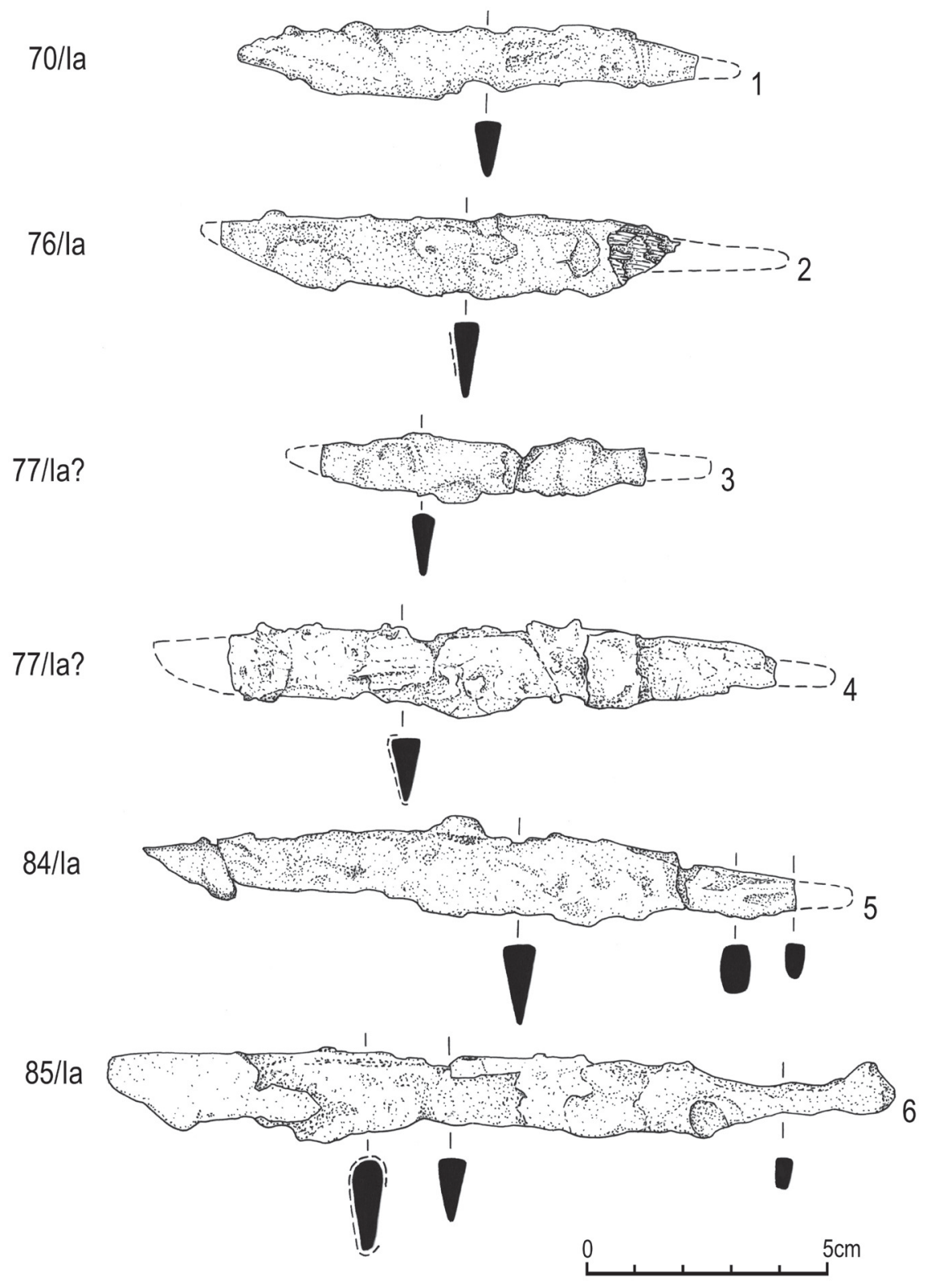

Ryc. 3. Noże żelazne typu Ia wg R. Rogosza (1983) z grobów nr: 70, nóż nr 3 (1), 76 (2), 77, nóż nr 2 (3), 77, nóż nr 1 (4), 84 (5) i 85 (6). Rys. Wiktor Kudra i Jolenta Kędelska, oprac. komp. Jolenta Kędelska 
pochówkach, które prócz nie tylko większej długości charakteryzowały się także posiadaniem osobnych skórzanych pochewek spiętych wspólnym brązowym okuciem ( $w$ jednym przypadku dodatkowo złoconym), nadto bogato zdobionym, m.in. stylizowaną głową bestii-gryfa, jak w przypadku okucia z grobu nr 148 (ryc. 14:3), czy też całkowicie zeschematyzowanym analogicznym wizerunkiem, jak w przypadku okucia z grobu nr 151 (ryc. 14:2). Podobny jak w Sowinkach przypadek występowania noży parami zarejestrowano także w grobach komorowych $\mathrm{nr} 13$ i 60 na cmentarzysku w Kałdusie, gdzie wyroby te również odznaczały się ponadprzeciętnymi cechami (Chudziak, Bojarski, Stawska 2010, s. 83, tabl. 4g; 13a-b).

$\mathrm{Na}$ uwagę $\mathrm{w}$ tym zakresie zasługują jeszcze wyjątkowo trzy okazy noży znalezione w grobie $\mathrm{nr}$ 70. Niewątpliwie różnią się one między sobą zarówno długością (od 10,5 cm, poprzez $15 \mathrm{~cm}$ do ok. $20 \mathrm{~cm}$ ) oraz szczegółowymi cechami głowni oraz obecnością w dwóch przypadkach skórzanych pochewek i w jednym przypadku dodatkowo brązowego okucia (ryc. 13:1-2). Z uwagi na domniemaną profesję zmarłego - domniemanego kupca (Krzyszowski 1995, s. 49 i n.; 1997, s. 639-667) - trudno jest im przypisać ściśle określone funkcje specjalistyczne, niemniej - jak wyżej wspomniano - widoczne są różnice metryczno-typologiczne, które pozwoliły wyodrębnić trzy różne odmiany, które pośrednio mogą wskazywać być może na ich wielorakie zastosowanie.

Noże, mimo częstszego występowania aniżeli inne zabytki, nie mają jednakże większego znaczenia przy ustalaniu datowania zwartych zespołów grobowych. Jedynie okazy ze skórzanymi pochewkami i dodatkowo niejednokrotnie z metalowymi ozdobnymi okuciami wchodziły $\mathrm{z}$ reguły $\mathrm{w}$ skład wyposażenia grobów z wczesnych faz użytkowania XI i XII-wiecznych nekropoli (Knorr 1938, s. 513-515; Malinowska-Łazarczyk 1982, s. 28-30; Gabriel 1988, s. 161-171). Takich noży odkrytych w skórzanych pochewkach zanotowano na cmentarzysku w Sowinkach dość znaczną ilość, $\mathrm{w}$ tym niektóre $\mathrm{z}$ pochewek posiadały również metalowe okucia; te ostatnie noże i skórzane pochewki zostaną omówione poniżej.

\section{OPRAWKI RĘKOJEŚCI NOŻY}

U dziewięciu noży na ich trzpieniu zachowały się zmineralizowane fragmenty drewna, w które oprawiano rękojeść. Analiza tych szczątków dokonana przez prof. dr hab. Annę Lityńską-Zając z Instytutu Archeologii i Etnologii PAN Oddział w Krakowie wykazała (por. Lityńska-Zając 1994), iż w trzech przypadkach było to drewno pochodzące gatunkowo $\mathrm{z}$ sosny zwyczajnej (oprawka noża $\mathrm{z}$ grobu nr 134 i dwóch noży z grobu nr 148) oraz jednokrotnie z dębu (oprawka rękojeści noża z grobu nr 3). U pozostałych pięciu noży (z wyjątkiem jednego okazu) - nie udało się oznaczyć gatunku drewna, próbki były bowiem albo mocno zniszczone, albo mocno zmineralizowane, a tylko $\mathrm{w}$ jednej z tych próbek (dla rękojeści noża z grobu nr 414 (ryc. 10:2) określono ogólnie drewno jako pochodzące z drzew 


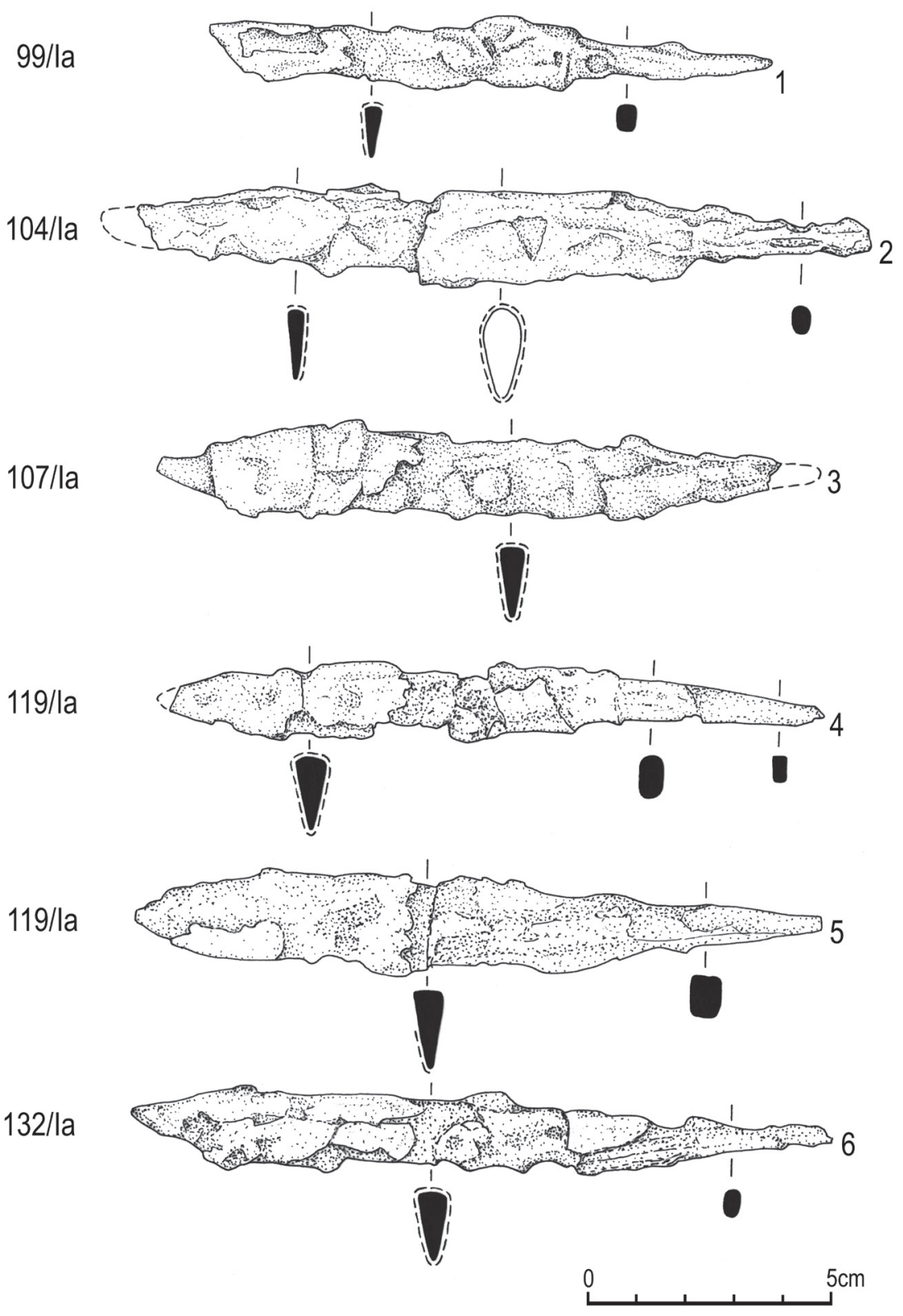

Ryc. 4. Noże żelazne typu Ia wg R. Rogosza (1983) z grobów nr: 99 (1), 104 (2), 107 (3), 119A (4), 119B (5) i 132 (6). Rys. Wiktor Kudra i Jolenta Kędelska, oprac. komp. Jolenta Kędelska 
szpilkowych. Jeszcze rzadziej stosowano oprawę rękojeści w kość względnie w poroże. Jedyną taką rękojeść pochodzącą z noża w grobie nr 69 (ryc. 13:4-5) dodatkowo ozdobiono koncentrycznymi kółkami, powszechnie spotykanym we wczesnym średniowieczu motywem ornamentacyjnym wykonywanym na przedmiotach z rogu, kości i poroża.

Ten ostatni zabytek stanowi niezwykle interesujący przykład dwustronnej okładziny wykonanej z poroża jeleniowatych ${ }^{3}$ z pięcioma żelaznymi nitami (o sklepanych półokrągłych główkach), która jest zdobiona motywem koncentrycznych kółek z wytłoczonym punktem wewnątrz każdego z nich, tworzących wespół z krótkimi odcinkami linii rytych powtarzalną kompozycję. Ornament ten został zapewne wykonany specyficznym narzędziem rzemieślniczym zwanym tłoczkiem -puncą, służącym m.in. do wybijania ornamentu punktowego, a następnie wypełniony substancją o ciemnym zabarwieniu (Rogosz 1983, s. 265). Omawiany przedmiot, niewątpliwie stanowiący okładzinę rękojeści noża z grobu $\mathrm{nr} 69$, można zaklasyfikować do typu $\mathrm{C}$ według podziału zaproponowanego przez A. Jastrzębskiego (2004, s. 255), tj. do okładzin dwudzielnych, o prostokątnym przekroju i płaskiej podstawie, które można datować w szerokich ramach od 2 połowy $\mathrm{X}$ do 1 połowy XIII wieku. Analogie do ornamentu oprawki noża z grobu nr 69 znajdujemy m.in. na pochewce z rogu kozy do żelaznego noża znalezionego na wczesnośredniowiecznym grodzie w Gnieźnie (Rajewski 1939a, ryc. 15).

\section{SKÓRZANE POCHEWKI NOŻY}

Noży odkrytych w skórzanych pochewkach zanotowano na cmentarzysku w Sowinkach dosyć znaczną liczbę, bo aż 36 egzemplarzy, co stanowi 51,4\% pośród wszystkich odkrytych okazów tego rodzaju przedmiotów. Oczywiście skórzane pochewki, jako że zostały wykonane bez wyjątku z części organicznych (skóry), $\mathrm{w}$ różnym stopniu zachowania przetrwały upływ czasu zarówno w jamach grobowych, jak i po ich wyjęciu. W większości zachowały się one w stanie fragmentarycznym, co również zostało zilustrowane $\mathrm{w}$ dokumentacji rysunkowej oraz fotograficznej noży. Pośród egzemplarzy z zachowanymi skórzanymi pochewkami u sześciu noży z pochewkami zachowały się dodatkowo metalowe okucia, niekiedy ozdobne. W pierwszym rzędzie poniżej zostaną omówione skórzane pochewki, natomiast $\mathrm{w}$ dalszej kolejności zostaną zaprezentowane ich metalowe okucia.

Jedenaście noży z lepiej zachowanymi fragmentami skórzanych pochewek (z grobów nr 70, 99, 148, 151, 152, 157, 165, 176 i 414) poddano szczegółowej ekspertyzie w zakresie użytego rodzaju skóry, którą przeprowadziła dr Teresa Radek z Uniwersytetu Przyrodniczego we Wrocławiu (Radek 1994). Na tej podstawie

\footnotetext{
${ }^{3}$ Określenie prof. D. Makowieckiego z Instytutu Archeologii UMK w Toruniu, któremu serdecznie dziękuję za wykonanie identyfikacji.
} 
152/la

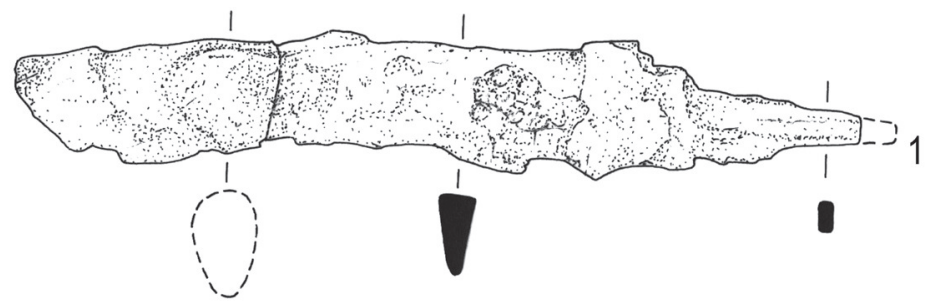

154/la

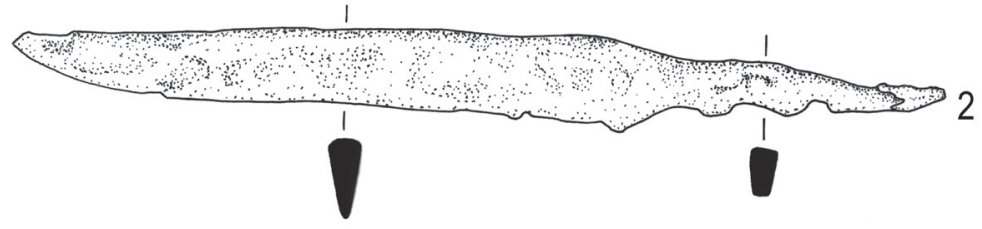

157/la

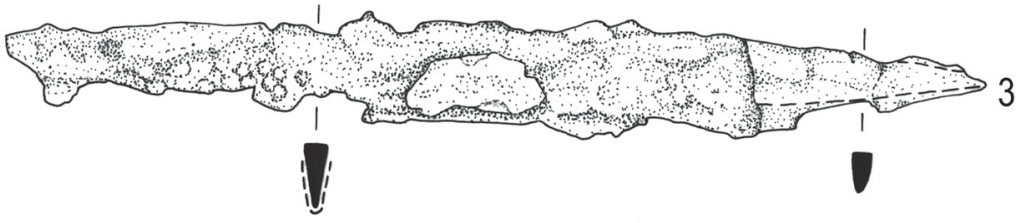

158/la?

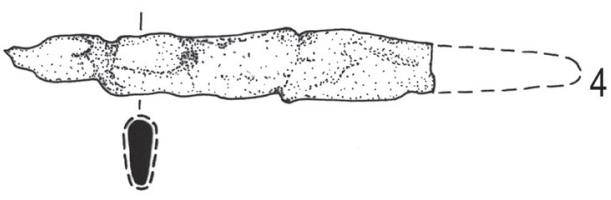

160/la

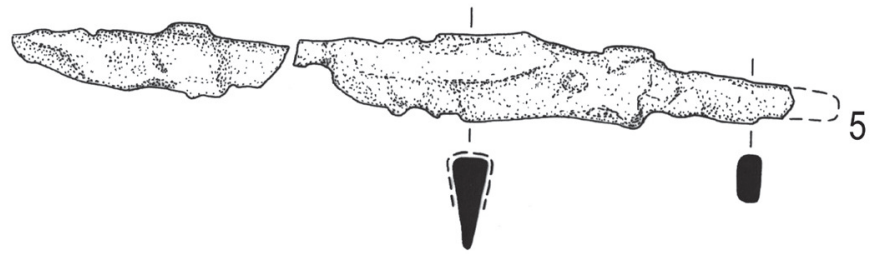

166/la
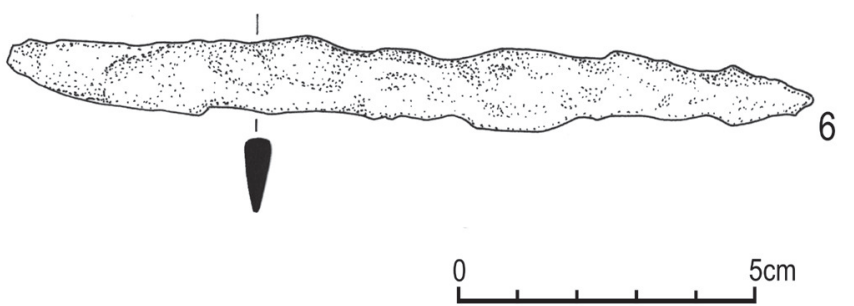

Ryc. 5. Noże żelazne typu Ia wg R. Rogosza (1983) z grobów nr: 152 (1), 154 (2), 157 (3), 158 (4), 160 (5) i 166 (6). Rys. Wiktor Kudra i Jolenta Kędelska, oprac. komp. Jolenta Kędelska 
można było stwierdzić, że wszystkie zbadane w tym zakresie noże wystąpiły w pochewkach ze skór garbowanych. W tym ostatnim aspekcie przyjmuje się, iż skóry garbowano najprawdopodobniej środkami roślinnymi (Wiklak 1963, s. 69-70).

Analiza ta wykazała użycie następujących rodzajów skór zwierzęcych jako pochewek noży z cmentarzyska w Sowinkach:

(a) skóry cielęcej w przypadku pochewki noża z grobu nr 70 (ryc. 13:2),

(b) skóry owczej lub cielęcej $\mathrm{w}$ pochewce jednego $\mathrm{z}$ dwóch noży $\mathrm{z}$ grobu nr 151 (ryc. $12: 1 ; 14: 2$ ),

(c) skóry ze zwierząt $\mathrm{z}$ rodziny jeleniowatych, którą stwierdzono $\mathrm{w}$ pochewce dwóch noży z grobu nr 148 (ryc. 11:1; 14:3) i w pochewce noża z grobu nr 414 (ryc. 10:1-2),

(d) skóry z łosia względnie jelenia, która $\mathrm{z}$ kolei wystąpiła $\mathrm{w}$ pochewce drugiego z noży z grobu nr 151 (ryc. 12:2).

Para noży z grobów nr 148 i 151, które miały osobne pochewki skórzane na każdy z dwóch noży została przed ich zdeponowaniem dodatkowo owinięta w rodzaj „pojemnika” ze skóry, którego niewielkie fragmenty się zachowały. Analiza takiej próbki z grobu nr 148 wykazała, że wyrób ten będący być może rodzajem kołczanu, może „futerału” (?), wykonano najprawdopodobniej ze skóry ssaków wodnych (R a d e k 1994).

Pośród zachowanych fragmentarycznie skórzanych pochewek szczególną uwagę zwracają lepiej zachowane od innych dwa fragmenty. Pierwszy pochodzi z pochewki noża z grobu nr 70 (ryc. 13:2). Zachował się tu bowiem fragment skrzydełka wąskiej pochewki, o łukowato ściętej części dolnej, który wykonano z jednego kawałka garbowanej skóry cielęcej, obecnie rozdwojonej, o spękanym lico, której krańce zszyto kilka milimetrów od brzegu dość regularnym pojedynczym ściegiem tzw. przetykanym, a dodatkowo wzmocniono brązowym trzewikiem z nitem, po którym zachował się ślad po otworze, a wymiary zachowanej skórzanej pochewki wynoszą: długość $-3 \mathrm{~cm}$, szerokość $-2,3 \mathrm{~cm}$, grubość $-1,5 \mathrm{~mm}$. Analogię do szwu szytego tzw. ściegiem przetykanym na fragmencie skóry znajdujemy m.in. z badań wykopaliskowych w Gnieźnie (Rajewski 1939b, ryc. 3). Podobny kształt o łukowato ściętej dolnej części skórzanej pochewki stwierdzono - na podstawie zachowanych zmineralizowanych fragmentów skórzanych pochewek oraz brązowych trzewików - w przypadku pochewek noży z kolejnych grobów nr 148, 165 i 176.

Z kolei z grobu nr 151 pochodzi fragment pochewki czy właściwiej krańce z dwóch odrębnych, połączonych ze sobą pochewek kryjących dwa oddzielne noże, spiętych u dołu jednym wspólnym (zewnętrznym) brązowym okuciem, przymocowanym do skóry metalowymi nitami (ryc. 12:3). Kształt zachowanych fragmentów tych dwóch odrębnych skórzanych pochewek $\mathrm{z}$ tego grobu przybiera $\mathrm{w}$ zakończeniu (w partii dolnej) tym razem formę prostokątną. Podobnie został ukształtowany kraniec skórzanej pochewki w zrekonstruowanej pochewce noża z grobu $\mathrm{nr} 414$; w tym przypadku na wiarygodną interpretację przedstawionej formy zakończenia 
$168 / \mathrm{la}$

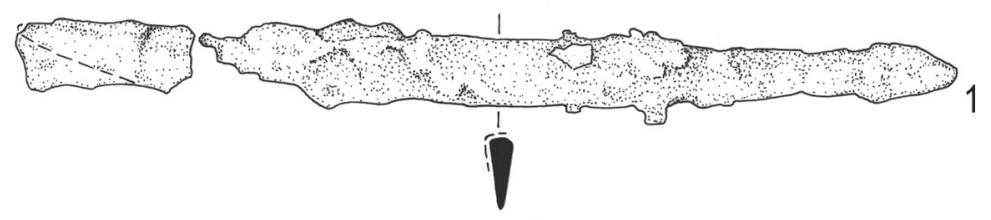

183/la
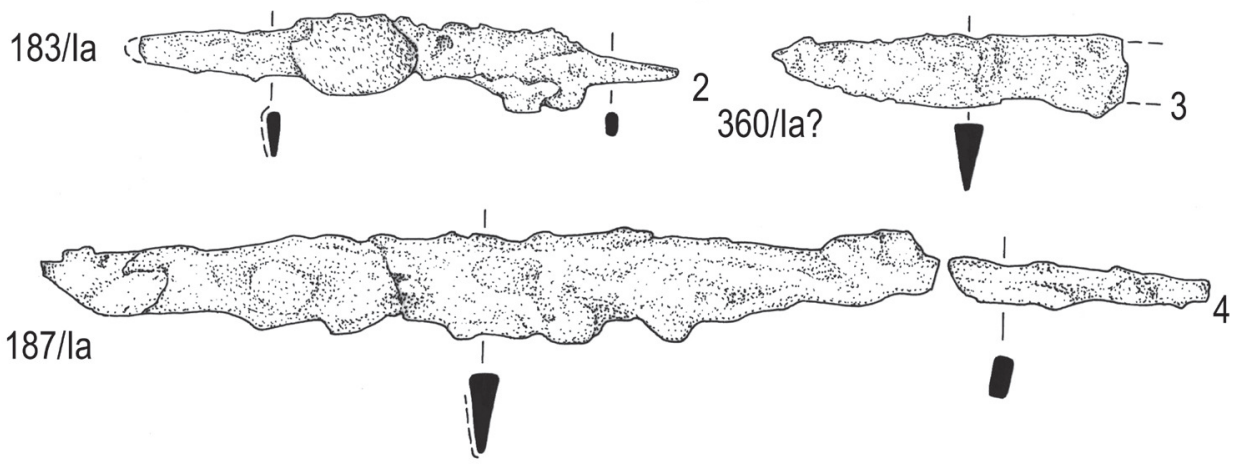

199/la

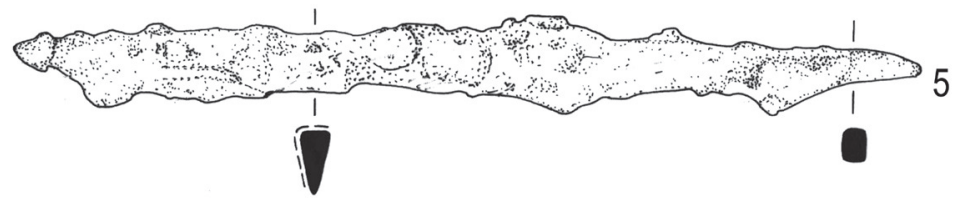

201/la

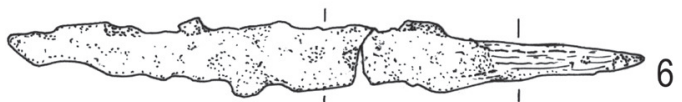

245/la

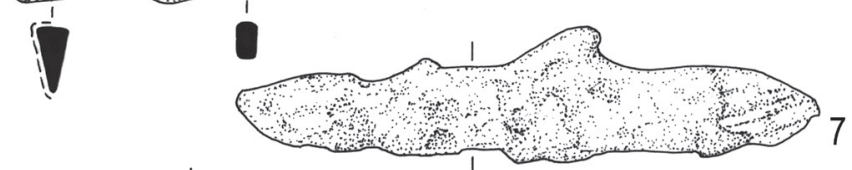

362/la

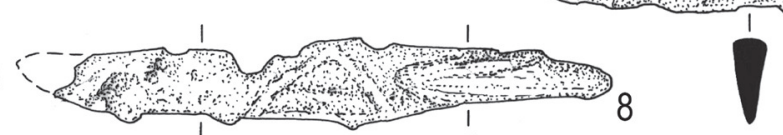

366/la

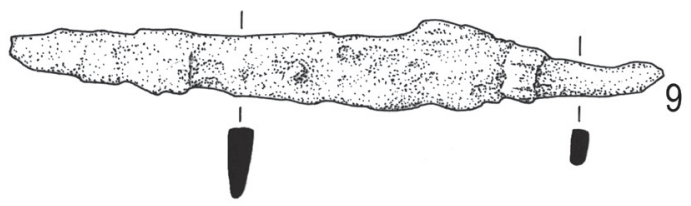

Ryc. 6. Noże żelazne typu Ia wg R. Rogosza (1983) z grobów nr: 168 (1), 183 (2), 360 (3), 187 (4), 199 (5), 201 (6), 245 (7), 362 (8) i 366 (9). Rys. Wiktor Kudra i Jolenta Kędelska, oprac. komp. Jolenta Kędelska 
tej pochewki miał wpływ zachowany jej skórzany fragment $\mathrm{z}$ tkwiącym $\mathrm{w}$ niej brązowym ozdobnym nitem (ryc. 10:1).

Pochewki o formie jak z wyżej wymienionych grobów były pierwotnie najprawdopodobniej przytroczone do pasa i służyły do noszenia noży względnie kamiennych osełek. Na podstawie badań z innych stanowisk wczesnośredniowiecznych, takich jak Wolin (Wojtasik 1960, s. 159-208) czy Gdańsk (Wiklak 1963, s. 67-81) wynika, że starsze chronologicznie skórzane pochewki (datowane na 2 połowę IX wieku) były starannie wykrojone, miały skrzydełka i były zszywane ściegiem zwykłym lub przetykanym. Natomiast pochewki „młodsze” (z końca XII w.) były prostsze w kroju i zszyte ściegiem na okrętkę. Pochewki tego rodzaju z Sowinek, w tym jak z jej lepiej zachowanym fragmentem z grobu nr 70 (ryc. 13:2) - reprezentują formę starszą chronologicznie, ponieważ były one zszywane ściegiem pojedynczym, przetykanym (Hołubowicz 1956, s. 128; Wiklak 1963, ryc. 12; Rajewski 1937, s. 109-113; Nadolski, Abramowicz, Poklewski 1959, s. 92-93; Wojtasik 1960, tabl. VIII:12, 15, IX:13).

Surowcem do „produkcji” pochewek noży była na stanowiskach wczesnośredniowiecznych przeważnie skóra bydlęca i końska (J. Wojtasik 1960, s. 180). Zaprezentowany wyżej rejestr skór użytych do wykonania pochewek noży z Sowinek wykazuje dość duże zróżnicowanie użytego surowca, albowiem prócz skóry cielęcej (bydlęcej) wystąpił tu zarówno surowiec pochodzący jeszcze z innych zwierząt domowych (owcy), ale również ze zwierząt dzikich (jelenia i łosia).

\section{METALOWE OKUCIA SKÓRZANYCH POCHEWEK NOŻY}

Jak wyżej wspomniano, na niektórych nożach z Sowinek, które miały zachowane częściowo skórzane pochewki, znajdowały się również ich metalowe okucia. Wystąpiły one $\mathrm{w}$ postaci okuć (tzw. trzewików) złożonych z podwójnej blachy z brązu, które miały łukowaty wykrój podstawy (w dwóch przypadkach był on mocno wydłużony) i które były mocowane do skórzanych krawędzi pochewek ozdobnymi nitami lub dodatkowo okuciami z taśmy i drutu brązowego. W Sowinkach przedmioty te znaleziono w sześciu grobach, z których jeden to pochówek dziecięcy (grób nr 414), jeden kobiecy (grób nr 165), a pozostałe to najpewniej pochówki męskie (grób $\mathrm{nr} 70,148,151$ i 176), choć te ostatnie w opinii antropologicznej pozostają nadal pochówkami nierozpoznanymi pod względem płci (por. tabela 1).

Zarówno brązowe „trzewiki”, jak i okucia z taśmy czy drutu były w większości zdobione motywami wytłaczanych (puncowanych) guzków. Trzy z tych pochewek reprezentują standardowy typ okuć o kształcie pantofelkowym (okucia z grobów nr 70, 165 i 414; ryc. 10:1-2; 13:1,3), które odpowiadają wyróżnionemu dla terenów Pomorza zachodniego typowi VIb według typologii H.A. Knorra (1938, s. 499, ryc. 9) i uznawane są powszechnie za wytwór typowo słowiański. Natomiast 


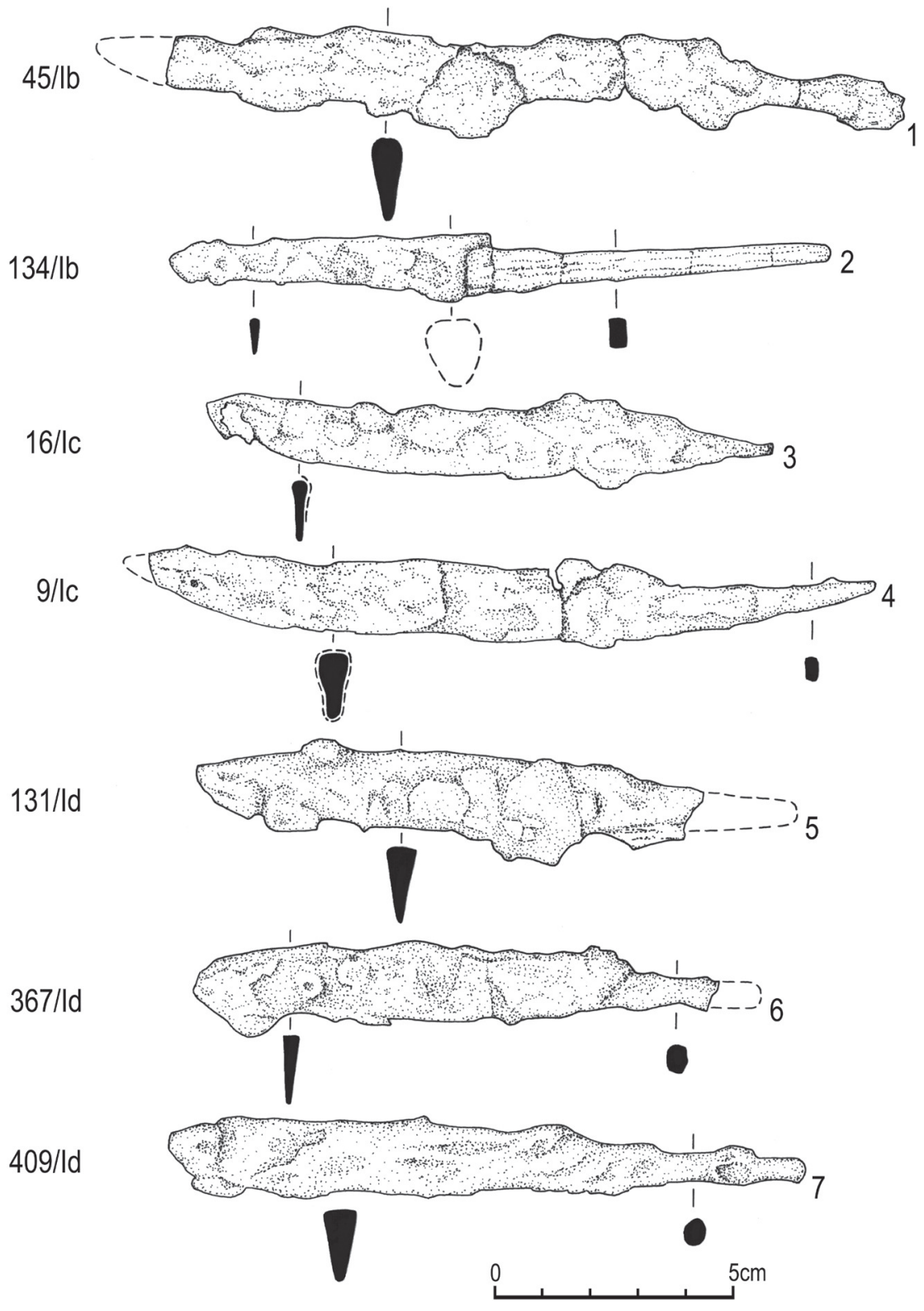

Ryc. 7. Noże żelazne typu Ib (1-2), Ic (3-4) i Id (5-7) wg R. Rogosza (1983) z grobów nr: 45 (1), 134 (2), 16 (3), 9 (4), 131 (5), 367 (6) i 409 (7). Rys. Wiktor Kudra i Jolenta Kędelska, oprac. komp. Jolenta Kędelska 
pochewki z trzech kolejnych grobów (nr 148, 151 i 176; ryc. 10:4-5; 11:3; 12:3; 14:2-4) wykazują zarówno w ukształtowaniu „trzewika” (również typu pantofelkowatego), lecz o wydłużonej podstawie, ornamentyce, jak i w konstrukcji dodatkowych okuć oraz $\mathrm{w}$ formie ich zakończeń $\mathrm{z}$ elementami zoomorficznymi - nawiązania do pochewek z terenów skandynawsko-bałtyjskich (Knorr 1938, s. 533-539, ryc. 12-13, 47-49; Arbman 1940-1943, Taf. 6:1a, 2ab, 6a, 7, 177:3, 178, 179:1). Dodatkowo na jednej z tego typu pochewek (z grobu $\mathrm{nr}$ 148; ryc. 14:3) wykonano złocenie brązowej blachy trzewika, co niewątpliwie świadczy o ekskluzywności tego wyrobu, w porównaniu do na ogół standardowych skórzanych pochewek znalezionych przy innych pochówkach.

Szczegółowy zestaw metalowych okuć do skórzanych pochewek noży z cmentarzyska w Sowinkach obejmuje sześć tego rodzaju przedmiotów o następujących odmianach:

(a) okucie z grobu $\mathrm{nr} 70$, pochodzące $\mathrm{z}$ pochewki noża $\mathrm{nr} 1$ typu If wg typologii R. Rogosza (nr 24 w tabeli nr 1; ryc. 13:1): jest wykonane z cienkiej blachy brązowej (o wymiarach: długość $-3,6 \mathrm{~cm}$, szerokość - 2,6 cm, grubość - 0,9-0,8 cm), zgiętej pierwotnie w pół, o łukowatym wykroju podstawy, jego brzegi przytwierdzone są do skórzanej pochewki brązowymi nitami, jest ono zdobione wzdłuż krawędzi wytłaczanym ornamentem w postaci szeregu wypukłych guzków, ponadto do wewnętrznej części okucia przytwierdzone są fragmenty tkaniny, w okuciu tkwił nit brązowy (o długości $32 \mathrm{~mm}$ i średnicy $14 \mathrm{~mm}$ ), pierwotnie po drugiej stronie okucia znajdował się drugi nit $\mathrm{z}$ brązu o analogicznej główce i trzpieniu;

(b) okucie z grobu nr 148 (ryc. 11:3; 14:3): na całkowicie zachowanych dwóch żelaznych nożach typu If wg klasyfikacji R. Rogosza tkwiących w dwóch odrębnych skórzanych pochewkach o wykroju prostokątnym i połączonych dołem w jedną wspólną pochewkę stwierdzono metalowy brązowy „trzewik” o kształcie pantofelkowatym, ale o wydłużonej podstawie, zdobionym na krawędzi blaszki ornamentem w postaci maleńkich, wytłaczanych i wypukłych guzków, następnie na część metalowego „trzewika” został nałożony brązowy pręt (o przekroju płasko-wypukłym), składający się z trzech różnych i odrębnie łączonych części: pierwszej nałożonej bezpośrednio na trzewik $\mathrm{w}$ postaci gładkiego pręta $\mathrm{z}$ dwoma motywami roślinnymi i z trzema otworami na nity oraz w zakończeniu lekko łukowato wygiętego i zakończonego stylizowaną głową bestii-gryfa, a kolejno nałożonych bezpośrednio na kraniec skórzanej pochewki dwóch kolejnych części pręta, pierwszego (środkowego) w postaci gładkiego pręta zdobionego również stylizowanymi elementami roślinnymi, wewnątrz których znajdowały się trzy otwory na nity, i ostatniej części składającej się z pręta ukośnie pseudotordowanego, także z zachowanymi trzema otworami na nity, ale również w partii środkowej wyraźnie poszerzonego w postaci prostokątnego otworu, służącego niewątpliwie do nanizania na rzemień i przytroczenia całości do pasa, wymiary metalowych okuć: całkowita długość trzewika - około $8,0 \mathrm{~cm}$, brązowy pręt: długość części ze stylizowaną głową bestii-gryfa $-7,3 \mathrm{~cm}$, długość partii środkowej pręta $-7,8 \mathrm{~cm}$, długość 

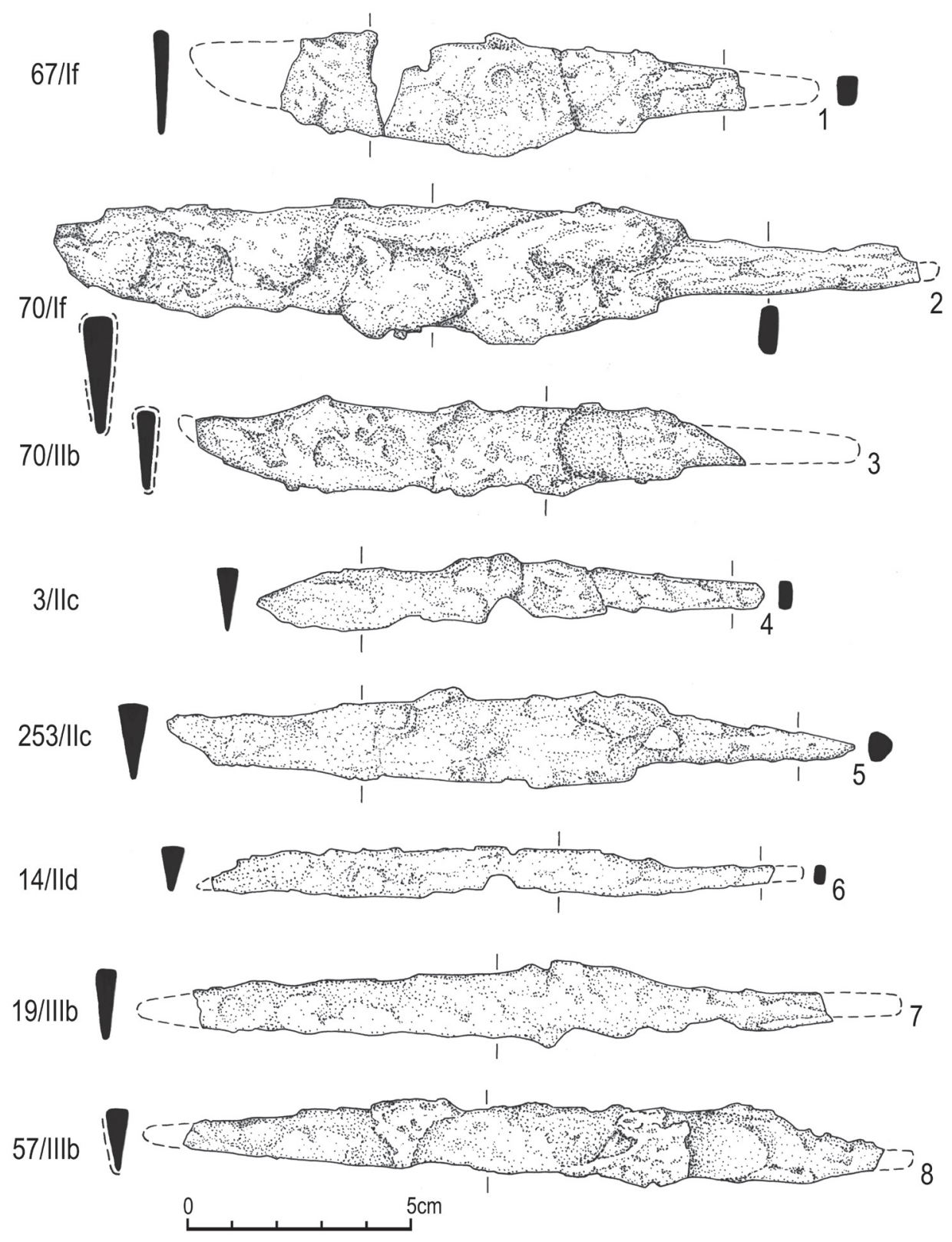

Ryc. 8. Noże żelazne typu If (1-2), IIb (3), IIc (4-5), IId (6) i IIIb (7-8) wg R. Rogosza (1983) z grobów nr: 67 (1), 70, nóż nr 1 (2), 70, nóż nr 2 (3), 3 (4), 253 (5), 14 (6), 19 (7) i 57 (8). Rys. Wiktor Kudra i Jolenta Kędelska, oprac. komp. Jolenta Kędelska 
pręta ukośnie tordowanego - 12,4 cm; szerokość pręta - 4-5 mm, grubość pręta $-3 \mathrm{~mm}$;

(c) okucie z grobu nr 151 (ryc. 12:3; 14:2): na całkowicie zachowanych dwóch żelaznych nożach typu If wg klasyfikacji R. Rogosza tkwiących podobnie jak w grobie nr 148 - w dwóch odrębnych skórzanych pochewkach o wykroju prostokątnym i połączonych dołem w jedną wspólną pochewkę nie stwierdzono tym razem metalowego „trzewika”, a jedynie nałożony bezpośrednio na skórę brązową taśmę (o przekroju prostokątnym), składającą się z dwóch oddzielnych części, pierwszą zakończoną łukowatym zagięciem i drugą o prostym przebiegu, które zostały przytwierdzone do skóry sześcioma brązowymi nitami (po 3 nity na każdą część taśmy), dzielącymi zarazem ornamentowane zewnętrzne partie obu taśm w postaci przecinających się w krzyż ukośnych rytych odcinków (w ciągłym wątku), każde z zakończeń obu odrębnych taśm są uformowane w mocno zeschematyzowaną główkę zwierzęcą, przypominającą również paszczę bestii-gryfa, wymiary dolnej taśmy zakończonej łukowatą końcówką: długość $-10,0 \mathrm{~cm}$, długość drugiej taśmy $-11,0 \mathrm{~cm}$, szerokość obu taśm $-5 \mathrm{~mm}$, grubość obu taśm $1,7 \mathrm{~mm}$, nity: długość $-3-4 \mathrm{~mm}$, średnica trzpienia $1,5 \mathrm{~mm}$, średnica główki $-2 \mathrm{~mm}$;

(d) okucie z grobu nr 165 (ryc. 13:3; 14:1): na prawie całkowicie zachowanym żelaznym nożu typu Ia wg klasyfikacji R. Rogosza zachowała się nieznacznie uszkodzona metalowa pochewka $\mathrm{z}$ cienkiej blaszki brązowej, zgiętej w pół, o łukowatym (pantofelkowatym) wykroju podstawy, okucie to było przytwierdzone do skórzanej pochewki noża małymi brązowymi nitami, z których zachowały się dwa nity, które mają lekko wypukłe główki, zachowane wymiary okucia: długość $3,3 \mathrm{~cm}$, szerokość $-1,7 \mathrm{~cm}$, grubość $-0,6 \mathrm{~mm}$, wymiary brązowych nitów: długość - $3 \mathrm{~mm}$, średnica główki - $4 \mathrm{~mm}$, średnica trzpienia - 2,5 mm;

(e) okucie z grobu nr 176 (ryc. 10:4-5; 14:4): na nieznacznie zniszczonym żelaznym nożu typu Ia wg R. Rogosza zachowało się nieuszkodzone brązowe okucie o kształcie pantofelkowatym, z wydłużoną podstawą, na którą nałożony jest brązowy pręt zdobiony zewnętrznie ukośnym pseudotordowaniem (o przekroju płasko-wypukłym) i zakończony stylizowaną postacią ptaka, do skórzanej pochewki zarówno wydłużona podstawa okucia, jak i nałożony na nią brązowy pręt zostały przytwierdzone dwoma brązowymi nitami o płaskich główkach, w dwóch specjalnie spreparowanych otworach na ww. pręcie, z kolei skórzana pochewka (na przedłużeniu ww. podstawy okucia i pręta została również spięta dwoma dodatkowymi brązowymi nitami, ale o główkach lekko wypukłych, wymiary okucia: całkowita długość - 8,0 cm, długość wydłużonej podstawy - około 4,5 cm, szerokość okucia $-1,8 \mathrm{~cm}$, szerokość wydłużonej podstawy $-8 \mathrm{~mm}$, długość pręta $-8,2 \mathrm{~cm}$, szerokość $-5 \mathrm{~mm}$, przekrój płasko-wypukły o grubości $-3 \mathrm{~mm}$;

(f) okucie z grobu nr 414 (ryc. 10:1-2): na żelaznym nożu, prawdopodobnie typu Ia wg R. Rogosza zachowała się uszkodzona pochewka (w kilku fragmentach) z cienkiej blaszki brązowej, zgiętej w pół, o łukowatym wykroju podstawy (typu 


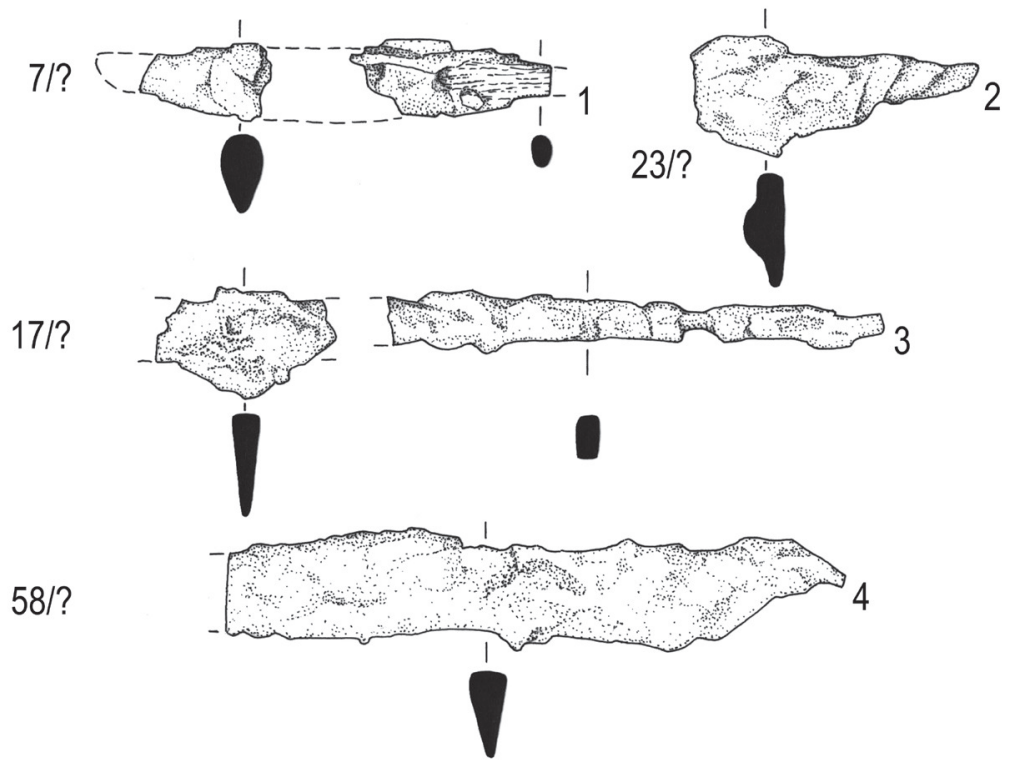

$62 / ?$

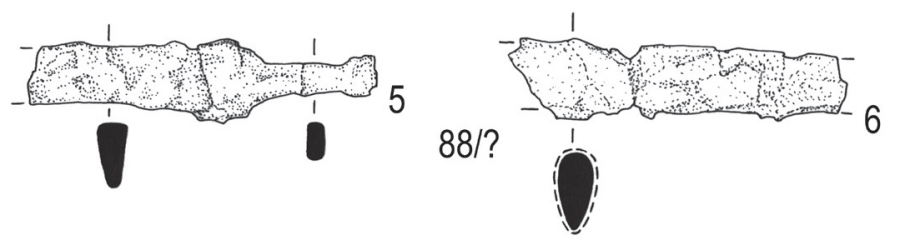

95/?
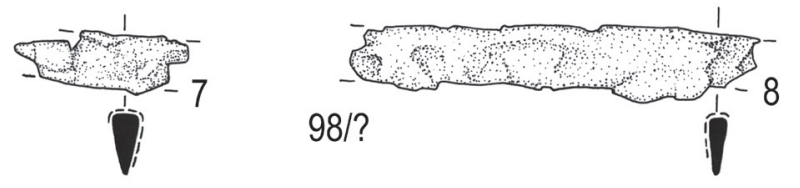

$102 / ?$
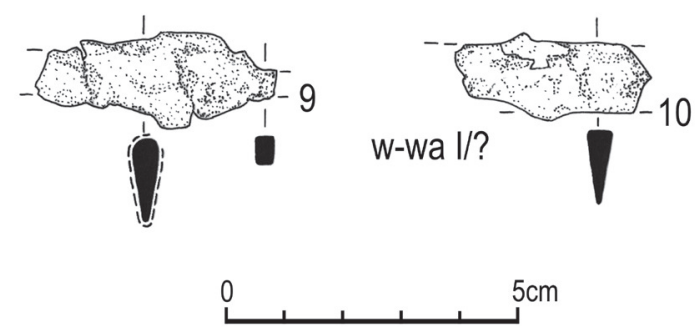

Ryc. 9. Noże żelazne typów nieokreślonych z grobów nr: 7 (1), 23 (2), 17 (3), 58 (4), 62 (5), 88 (6), 95 (7), 98 (8), 102 (9) i luźno z warstwy I, na arze 12B w wykopie WI/1989 (10).

Rys. Wiktor Kudra i Jolenta Kędelska, oprac. komp. Jolenta Kędelska 
pantofelkowatego); na zewnętrznej krawędzi blaszki znajduje się ornament w postaci maleńkich, wytłaczanych, wypukłych guzków, okucie to było przytwierdzone do skórzanej pochewki trzema małymi brązowymi nitami, z których zachowały się dwa nity; oprócz ww. nitów krańce skórzanej pochewki były skute i zarazem ozdobione pięcioma brązowymi nitami (ryc. 10:1-3), umieszczonymi w partii podłużnej pochewki (w zastępstwie taśmy lub brązowego drutu), te ostatnie nity w liczbie pięciu egzemplarzy (w dwóch odmianach; ryc. 10:3) miały wypukłe główki o kształcie prostokątnym z umieszczonym pośrodku kolcem, zachowane wymiary okucia: długość - 3,3 cm (długość zrekonstruowana - 4,5 cm), szerokość - 1,7 cm (szerokość zrekonstruowana $-2,7 \mathrm{~cm}$ ), grubość $-0,6 \mathrm{~mm}$, wymiary brązowych nitów na okuciu: długość $-3 \mathrm{~mm}$, średnica główki $-4 \mathrm{~mm}$, średnica trzpienia 2,5 mm, wymiary brązowych nitów umieszczonych w dolnej partii skórzanej pochewki: długość trzpienia, wymiary kwadratowej główki -8 × $8 \mathrm{~mm}$.

Okres najpowszechniejszego użytkowania metalowych okuć pochewek noży przypada na XI-XII wiek (Knorr 1938, s. 513-515; Gabriel 1988, s. 161-171). I tak okucie z grobu $\mathrm{nr} 70$ o kształcie pantofelkowatym odpowiada typowi VIb wg klasyfikacji H.A. Knorra dla okazów tego rodzaju z Pomorza Zachodniego (Knorr 1938, s. 499, ryc. 9). Okres najpowszechniejszego ich użytkowania przypada na XI w., względnie na początki XII wieku (Knorr 1938, s. 513-515; Gabriel 1988, s. 61-71; Nadolski, Abramowicz, Poklewski 1959, s. 93). Pierwsza część tej daty mieści się w chronologii omawianego grobu, dla którego również mamy datę $14 \mathrm{C}$ (por. ryc. 1; Michalska, Krzyszowski 2017, Table 2). Standardowe okucia, jakie zanotowano $\mathrm{w}$ grobach $\mathrm{nr} 70 \mathrm{i} 165 \mathrm{w}$ Sowinkach, znane są z kilku stanowisk z terenu Pomorza, tj. m.in. z Pruszcza Gdańskiego (Lęga 1930, s. 231, ryc. 55: 347; Zoll-Adamikowa 1975, s. 191, ryc. 94a), Gdańska (Hołowińska 1959, tabl. 9:17), Wielkopolski: z Komorowa (Rajewski 1937, s. ryc. 9:13), z Młodzikowa (Leciejewicz, Łosiński 1960, s. 142, ryc. 61:6) czy Polski Środkowej: z Lutomierska (Nadolski, Abramowicz, Poklewski 1959, s. 92-93, tabl. 71:6).

Z kolei analogie do metalowych pochewek noży z grobów nr 148 i 151 z Sowinek znajdujemy zarówno $\mathrm{z}$ obszarów zachodniosłowiańskich, jak i z terenów skandynawsko-bałtyjskich. I tak do okucia noża pochewki z grobu nr $151 \mathrm{~W}$ postaci wąskiej taśmy brązowej zakończonej mocno zeschematyzowaną główkę zwierzęcą, w rodzaju otwartej paszczy bestii-gryfa znajdujemy m.in. na cmentarzysku na wzgórzu „Młynówka” w Wolinie (Wojtasik 1970, s. 312, tabl. II:24). Podobne do okucie jak z grobu nr 151 publikuje też T.J. Arne (1931, Abb. 29ab), które zostało znalezione w jednym ze skandynawskich grobów na terenie Ukrainy. Zbliżone okazy odkryto również na cmentarzysku w Birce (Arbman 1940-1943, tabl. 178:1 - w grobie 151; 178:2 - w grobie 968; 179:1 - w grobie 950).

Do bogato zdobionego i pozłacanego okucia z grobu nr 148 podobieństwa znajdujemy $\mathrm{z}$ kolei w brązowym okuciu znalezionym na grodzie w Grzybowie (Tuszyński 2003, ryc. 76) oraz z dwóch grobów komorowych na cmentarzysku w Kałdusie (Chudziak, Bojarski, Stawska 2010, s. 83). W tym pierwszym przy- 


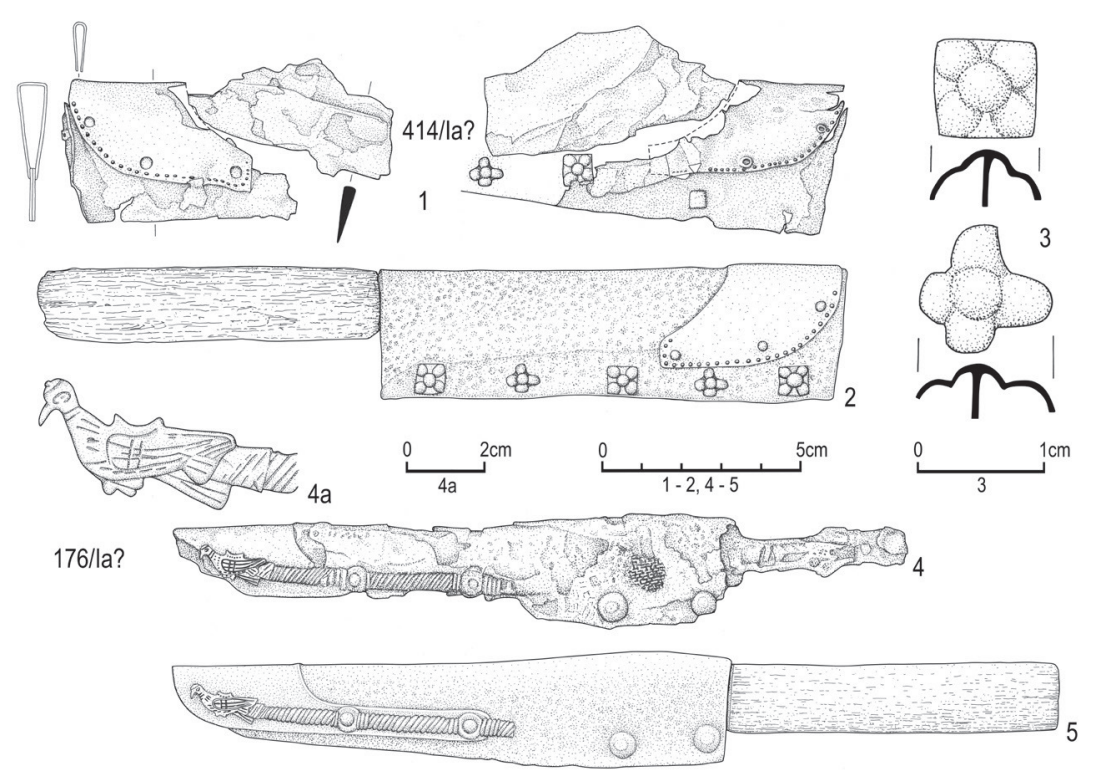

Ryc. 10. Noże żelazne typu Ia wg R. Rogosza (1983) z brązowymi okuciami skórzanych pochewek z grobów nr: 414 (1-3) i 176 (4-5); 1,4 - stan rzeczywisty po konserwacji, 2,5 rekonstrukcje noży, 3 - brązowe guzki w powiększeniu, 4a - przedstawienie zakończenia okucia-ptaka w powiększeniu. Rys. Wiktor Kudra i Jolenta Kędelska, oprac. komp. Jolenta Kędelska

padku okucie jest niekompletne, ale w formie i stylistyce zdobnictwa wydaje się zbliżone do okucia z omawianego grobu $\mathrm{nr} 148 \mathrm{w}$ Sowinkach. Z kolei w przypadku okuć z Kałdusa, z grobów nr 13 i 60 (Chudziak, Bojarski, Stawska 2010, s. 83, tabl. $4 \mathrm{~g} ; 13 \mathrm{a}-\mathrm{b})$ podobieństwo jest uderzające, i to zarówno w zakresie występowania noży parami (podobnie jak w grobie nr $148 \mathrm{w}$ Sowinkach), jak i w formie i rodzaju brązowych okuć oraz ich zakończeń. Te ostatnie wystąpiły tutaj również w postaci stylizowanego wyobrażenia głów bestii-gryfa/węża, symboliki niewątpliwie o konotacjach skandynawsko-bałtyjskich. Nie wnikam głębiej w interpretację owej symboliki, odsyłając do jej prezentacji autorstwa W. Chudziaka (2001, s. 70 i n.; 2002, s. 433 i n.; 2006, s. 67 i n.) oraz A. Koperkiewicza (2005, s. 282), niemniej nie ulega wątpliwości „obce” pochodzenie tej ornamentacji. Prawdopodobnie motyw ten $\mathrm{w}$ ikonografii wikińskiej można łączyć $\mathrm{z}$ okresem przejściowym między stylami Jellinge a Mammen i datować na okres od 2 połowy X do 1 połowy XI w. (Wilson, Klindt-Jensen 1966). Również według cenionego badacza tej problematyki H.A. Knorra (1938, s. 513-515) tego rodzaju okucia pochewek występują powszechniej między XI-XII wiekiem. 
W końcu na uwagę zasługuje jeszcze okucie pochewki noża z grobu $\mathrm{nr}$ 176, zakończone stylizowanym, ale zarazem dość realistycznym przedstawieniem ptasim (ryc. 10:4). Według ekspertyzy autorstwa prof. Aleksandra Winieckiego (Winiecki 1994) z Uniwersytetu im. Adama Mickiewicza w Poznaniu przedstawionego w zakończeniu okucia pochewki z tego grobu tym ptakiem jest gołąb, natomiast nie można było jednoznacznie określić jego przynależności gatunkowej. W grę wchodzi bowiem kilka gatunków europejskich gołębi: turkawki, grzywacza, siniaka i gołębia skalnego (zwłaszcza jego udomowionej formy). Z kolei elementami „niebiologicznymi” w przedstawieniu tego ptaka - według autora tejże ekspertyzy są dobrze czytelne symbole kultury ludzkiej, którymi są zarys siodła umieszczonego na jego grzbiecie oraz nakrycie w formie „czapki” zlokalizowane na jego głowie. Ostatnim, jednakże wątpliwym w tej kwestii elementem kultury są graficznie zaprezentowane na skrzydle ptaka przez ówczesnego artystę kontury piór-lotek, ale możliwe, iż są to miecze. Analogie do tego typu zakończeń metalowych pochewek noży znajdujemy z obszarów zachodniofińskich, w tym również z obiektów grobowych (por. Okulicz-Kozaryn 1993, ryc. 87:11). Podobne przedstawienie wizerunku ptaka prezentuje uchwyt brązowego noża znajdującego się w zbiorach Muzeum Narodowego w Helsinkach z miejscowości Kuulaanmäki (Urjala, Tavastia) datowanego na okres V-VI w. (G 1 y n 1981, s. 88, ryc. 38). Ornament ptasich głów jest ponadto powszechnie uznawany za typowo fiński. Prawdopodobnie z obszaru fińskiego znad Ładogi wywodzą się skórzane pochewki noży okute brązem, gdzie powstały już w X w., i skąd ich powszechniejszą produkcję podjęto następnie na terenach liwskich, gdzie wypracowano nawet ich miejscową odmianę określaną motywem „wilczego zęba” (Tõnisson 1974, tabl. XIX:2). Na terenach zachodniofińskich noże żelazne w pochwach były nieodłącznym atrybutem każdej kobiety i prawie wszystkich mężczyzn, a powszechność ich występowania przetrwała tam nawet do XV wieku (Okulicz-Kozaryn 1993, s. 179). Okucia z wyżej wymienionych miejsc uzasadniają chronologię omawianych sześciu okazów metalowych okuć skórzanych pochewek noży z Sowinek, lokując je we wskazanym wyżej przedziale chronologicznym od 2 połowy X do 1 połowy XI wieku.

\section{KWESTIA TECHNIK KOWALSKICH}

W zakończeniu omawiania tej partii zabytków uwagę poświęcimy jeszcze kwestiom technologicznym niektórych z nich. Dla 16 noży z Sowinek (22,8\% całości zbioru noży) przeprowadzono analizę metaloznawczą, wykonaną przez prof. Jerzego Piaskowskiego z Instytutu Odlewnictwa w Krakowie (opublikowaną w: Piaskowski 1999, s. 231-243). Analiza ta wykazała dość znaczne różnice technologiczne, co jest zbieżne dla produkcji wyrobów żelaznych na ziemiach Polski w XI-XII wieku. Autor ten wyodrębnił bowiem w analizowanym zbiorze z Sowinek cztery zasadnicze grupy technologiczne, ale aż dziesięć odrębnych ty- 
Tabela 2. SOWINKI, stan. 23a. Wyniki ilościowej analizy chemicznej noży (wg. J. Piaskowskiego 1999, s. 233-234, tabela 1 - z uzupełnieniami autora)

\begin{tabular}{|r|c|c|c|c|c|c|c|c|}
\hline Lp. & $\begin{array}{c}\text { Nr } \\
\text { grobu }\end{array}$ & Nr inw. & $\begin{array}{c}\text { Masa } \\
\text { (w gramach) }\end{array}$ & $\mathrm{P}$ & $\mathrm{Ni}$ & $\mathrm{Cu}$ & $\mathrm{Mn}$ & Rycina \\
\hline 1 & 2 & 3 & 4 & 5 & 6 & 7 & 8 & 9 \\
\hline 1 & $16^{1}$ & $43 / 1989$ & 15,2 & 0,64 & 0,003 & 0,013 & 0,046 & $7: 3$ \\
2 & 19 & $145 / 1989$ & 19,2 & 0,407 & 0,004 & 0,016 & 0,014 & $8: 7$ \\
3 & $44^{1}$ & $108 / 1989$ & 20,8 & 0,480 & 0,006 & 0,02 & 0,005 & $2: 4$ \\
4 & $61^{1}$ & $119 / 1989$ & 16,7 & 0,222 & 0,018 & 0,026 & 0,074 & $2: 6$ \\
5 & 69 & $128 / 1989$ & 40,7 & 0,370 & 0,042 & 0,018 & 0,003 & $12: 4$ \\
6 & $70^{1,2}$ & $132 / 1989$ & 62,4 & 0,420 & 0,037 & 0,017 & 0,008 & $8: 2$ \\
7 & 84 & $146 / 1989$ & 22,7 & 0,265 & 0,007 & 0,015 & 0,012 & $3: 5$ \\
8 & $14^{82}$ & $255 / 1989$ & 42,6 & 0,559 & 0,004 & 0,025 & 0,003 & $10: 2$ \\
9 & $16^{61}$ & $217 / 1989$ & 17,6 & 0,51 & 0,033 & 0,01 & 0,023 & $5: 6$ \\
10 & $18^{71}$ & $240 / 1989$ & 22,8 & 0,033 & 0,008 & 0,015 & 0,63 & $6: 4$ \\
11 & 199 & $235 / 1989$ & 20,7 & 0,16 & 0,014 & 0,03 & 0,014 & $6: 5$ \\
12 & 253 & $3 / 1990$ & 30,2 & 0,21 & 0,048 & 0,005 & 0,001 & $8: 5$ \\
13 & 362 & $90 / 1990$ & 20,1 & 0,55 & 0,040 & 0,02 & 0,005 & $6: 8$ \\
14 & $36^{61}$ & $96 / 1990$ & 12,9 & 0,21 & 0,005 & 0,03 & 0,007 & $6: 9$ \\
15 & $36^{71}$ & $93 / 1990$ & 17,5 & 0,33 & 0,038 & 0,035 & 0,055 & $7: 6$ \\
16 & $40^{91}$ & $153 / 1990$ & 24,6 & 0,31 & 0,03 & 0,039 & 0,015 & $7: 7$ \\
\hline
\end{tabular}

1 - średni wynik analizy wszystkich warstw; 2 - w grobie nr 70, to nóż nr 1, w grobie nr 148, to nóż $\mathrm{nr} 1 ; 3$ - prawdopodobnie głównie w żużlu

pów, jednak dla ośmiu noży (połowa zbadanych) użyto tu technologii zgrzewania z żelaza i stali (stal w formie nakładki lub w tzw. klasycznym wariancie „sandwich"), różniące się też szczegółowymi cechami technologicznymi.

Wśród noży z Sowinek na podstawie przeprowadzonej analizy metaloznawczej wyróżniono szczegółowo następujące typy morfologiczne (według klasyfikacji Piaskowskiego 1974a, s. 67-96):

(1) noże wykute tylko $\mathrm{z}$ żelaza, w zasadzie niepoddane żadnym procesom utwardzania - zakwalifikowano tu noże z grobów nr 69 i 84 (tabela 1, poz. 23 i 30 ; tabela 2, poz. 5 i 7; ryc. 15-16:5,7) lub noże ze śladowym, lokalnym nawęgleniem pierwotnym o charakterze raczej przypadkowym, które reprezentują okazy z grobów nr 148 i 362 (tabela 1, poz. 43 i 64; tabela 2, poz. 8 i 13; ryc. 15-16:8,13);

(2) noże wykute $\mathrm{z}$ żelaza nawęglanego, które wykazały nawęglenie jedynie w pobliżu krawędzi tnącej - zakwalifikowano tu noże z grobów nr 19 i 366 (tabela 1, poz. 9 i 65; tabela 2, poz. 2 i 14; ryc. 15-16:2,14);

(3) noże wykonane ze stali, o niskiej zawartości węgla (do ok. 0,1\% C), prawie nieróżniącej się od żelaza - zaliczono tu noże z grobów nr 199 i 253 (tabela 1, poz. 59 i 62; tabela 2 , poz. 11 i 12; ryc. 15-16:11-12); w strukturze noża z grobu 
nr 253 wystąpiły wprawdzie ślady obróbki cieplnej, ale niewykluczone, że być może przypadkowej;

(4) noże zgrzewane z żelaza i stali, ale różniące się szczegółowymi technikami zgrzewania, wszystkie okazy z częściami nawęglonymi lub stalowymi były poddawane dodatkowemu utwardzaniu przez obróbkę cieplną; pośród ośmiu egzemplarzy (50\% zbadanych noży) tego rodzaju noży szczegółowo wyróżniono:

(a) noże z żelaza wysokofosforowego z prostą nakładką stalową, stanowiącą jedynie ostrze, obrabiane cieplnie (typ IV.1.A.1 wg J. Piaskowskiego), które reprezentują dwa noże z grobów nr 16 i 44 (tabela 1, poz. 7 i 14; tabela 2, poz. 1 i 3; ryc. $15-16: 1,3)$;

(b) noże z żelaznym dwuwarstwowym grzbietem i z nakładką stalową stanowiącą ostrze, niedochodzącą do grzbietu, obrabiane cieplnie (typ IV.2.B.1 wg J. Piaskowskiego) - stanowi go pojedynczy egzemplarz z grobu $\mathrm{nr} 70$ (tabela 1, poz. 24; tabela 2, poz. 6; ryc. 15-16:6);

(c) noże z żelaznym trójwarstwowym grzbietem (z żelaza wysokofosforowego) ze zgrzaną nakładką stalową stanowiącą ostrze i niedochodzącą do grzbietu, obrabiane cieplnie (typ IV.1.B.1 wg J. Piaskowskiego) - odmiana ta jest reprezentowana przez pojedynczy egzemplarz z grobu nr 166 (tabela 1, poz. 54; tabela 2, poz. 9; ryc. 15-16:9);

(d) noże trójwarstwowe, zgrzewane, w których stalowa wkładka środkowa otoczona jest $\mathrm{z}$ obu stron zewnętrznych płatami $\mathrm{z}$ żelaza, są one obrabiane cieplnie (typ IV.2.B.2 wg J. Piaskowskiego; jest to typowy (klasyczny) nóż wykonany w pełni wykształconej technice typu „sandwich”, który reprezentuje pojedynczy okaz z grobu nr 61 (tabela 1, poz. 19; tabela 2, poz. 4; ryc. 15-16:4);

(e) noże z żelaznym dwuwarstwowym grzbietem i zgrzewaną wkładką stalową stanowiącą ostrze, ale niedochodzącą do grzbietu oraz z dodatkową boczną nakładką stalową, obrabiane cieplnie (typ IV.2.B.3 wg J. Piaskowskiego) - stanowi go pojedynczy okaz noża z grobu nr 367 (tabela 1, poz. 66; tabela 2, poz. 15; ryc. 15-16:15);

(f) noże pięciowarstwowe, w których środkowa wkładka stalowa posiada z obu stron warstwę żelaza i warstwę stalową, zewnętrzną wykonaną $\mathrm{z}$ niskowęglowej stali (są to noże zbliżone do typu IV.3.C.1 wg J. Piaskowskiego, a zarazem można go uznać za nóż wykonany w klasycznej technologii „sandwich”) - nóż tego rodzaju jest reprezentowany przez pojedynczy okaz z grobu nr 409 (tabela 1, poz. 67; tabela 2, poz. 16; ryc. 15-16:16);

(g) noże złożone z czterech lub pięciu warstw niskofosforowej stali i żelaza, o strukturze pasmowej, z prostą nakładką stalową, stanowiącą ostrze i część grzbietową, obrabiane cieplnie (typ IV.1.C.1 wg J. Piaskowskiego) - stanowi go pojedynczy okaz noża $\mathrm{z}$ grobu nr 187 (tabela 1, poz. 58; tabela 2, poz. 10; ryc. 15-16:10).

Uwagę w tej ostatniej grupie noży zwracają okazy z grobów $\mathrm{nr} 61,70,187$ i 409 - gdzie zastosowano bardzo cienkie warstewki, zapewne z żelaza arsenowego. Ponadto ekspertyza noża z grobu nr 187 wykazała w jego składzie resztki 

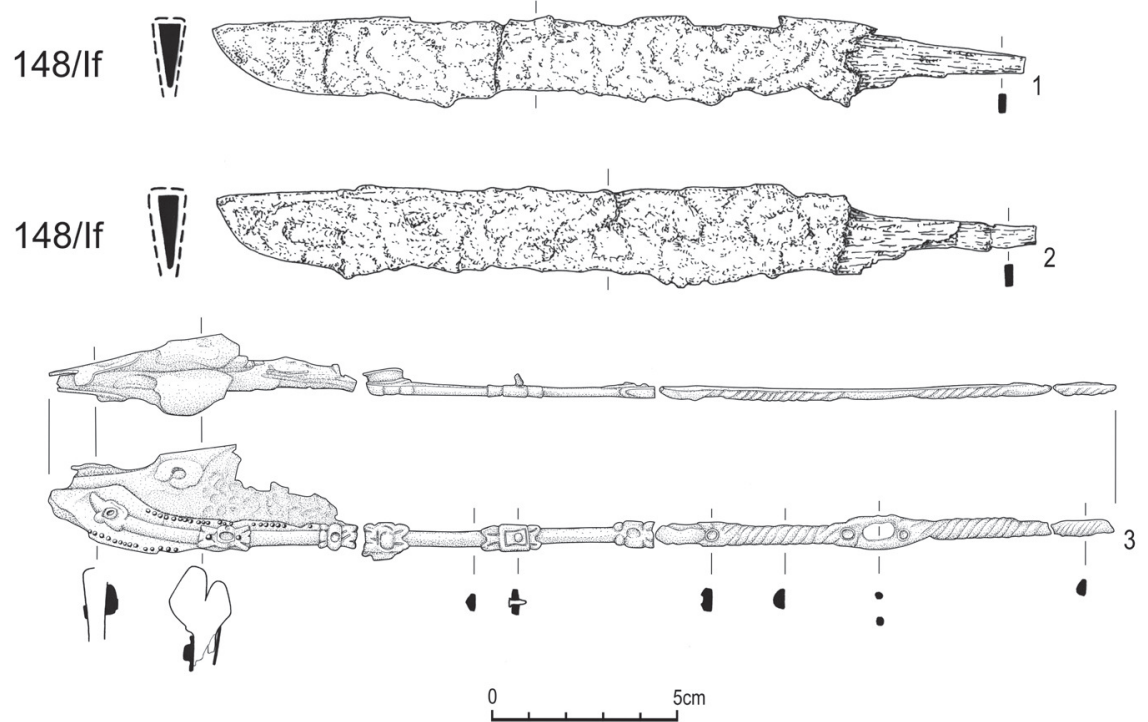

Ryc. 11. Noże żelazne typu If wg R. Rogosza (1983) (1-3) z brązowym okuciem skórzanej pochewki z grobu komorowego nr 148 (1 - nóż nr 1, 2 - nóż nr 2, 3 - pozłacane brązowe okucie wspólnej skórzanej pochewki). Rys. Wiktor Kudra i Jolenta Kędelska, oprac. komp. Jolenta Kędelska

wysokomanganowej (udział w 0,69\% Mn) i niskofosforowej rudy (ze średnią zawartością $0,033 \%$ P), na której złoża na ziemiach Polski dotychczas nie natrafiono. Autor omawianej analizy prof. J. Piaskowski uważa jednak, iż zawartość manganu w żelazie dymarskim była tutaj raczej wynikiem wtrąceń żużla. Wykonana mikroanaliza potwierdziła taką identyfikację, jednak nie udało się określić pochodzenia tych wtrąceń (Piaskowski 1999, s. 234-240). Przypomnijmy nadto, że w grobie tym pochowano mężczyznę zmarłego w wieku Adultus, wraz z monetą bitą w Trewirze (Krzyszowski, Suchodolski 2018, s. 156). Nie wykluczam, iż w tym wypadku może raczej wchodzić w rachubę ,import” gotowego wyrobu aniżeli import surowca stalowego do jego wyrobu. Podobnie interpretuje się zbliżoną sytuację w przypadku noży z wkładkami stalowymi o podwyższonej zawartości niklu znalezionymi w Gniezdovie (Kolčin 1953, s. 47, tab. 5, 136) czy na ziemi połockiej (Gurin 1987, s. 100 i n.) na Rusi Kijowskiej. Rudy darniowe czy błotne na tych terenach nie zawierają bowiem tego metalu, a domieszkę tę spotyka się dość często w skandynawskich złożach żelaznych, stąd przyjmuje się, iż przynajmniej w przypadku znalezisk z Połocka czy Witebska są to również importy gotowych noży aniżeli surowca stalowego (Gurin 1987, s. 27 i n., 30 i n.; Łosiński 1995, s. 42-43). 
Poza nożem z grobu nr 187, charakteryzującym się unikatowym typem technologii w postaci zgrzewania z 4-5 warstw niskofosforowej stali i żelaza, ale o strukturze pasmowej, i gdzie ostrze stanowiła stalowa nakładka - pozostałe $z$ tej grupy noże (z grobów $\mathrm{nr} 61,70,409)$ były zbudowane podobnie, $\mathrm{z}$ trzech warstw niskowęglowej stali, przedzielonych cienkimi warstewkami, ale tym razem $\mathrm{z}$ wysokofosforowego żelaza. Dwa $\mathrm{z}$ nich (z grobów $\mathrm{nr} 61$ i 409) zdecydowanie odpowiadają wykonaniu ich w klasycznej technologii „,sandwich”, a kolejny okaz (z grobu nr 70) w technologii mocno do niej zbliżonej (Łosiński 1995, s. 47; 2000, s. 498; Jagodziński 2010, s. 146, ryc. 208). Natomiast - jak obrazuje tabela 2 wszystkie pozostałe noże z Sowinek wykonano z żelaza i stali o podwyższonej zawartości fosforu mieszczącej się w granicach $0,16-0,64 \%$, przy średniej arytmetycznej wynoszącej $0,377 \%$ P lub $0,355 \%$ P, jeśli włączona zostanie także analiza noża z grobu nr 187.

Podobnie wysoką zawartość fosforu wykazują wyroby żelazne z innych wczesnośredniowiecznych stanowisk archeologicznych na ziemiach Polski, dla których średnie zawartości fosforu mieszczą się w granicach 0,200-0,420\% P. Mam tu na uwadze przebadane przedmioty żelazne $\mathrm{z}$ cmentarzyska $\mathrm{w}$ Lutomiersku, gdzie wskaźnik ten wynosi 0,211\% P (Piaskowski 1959c, s. 126-129; 1974, tabela 3), czy dla przedmiotów z kolejnego cmentarzyska w Buczku z nieco jeszcze wyższym wskaźnikiem zawartości fosforu - 0,364\% P (Piaskowski 1959a, s. 92). Wyjątkiem w tym względzie są tylko przedmioty żelazne $\mathrm{z}$ wczesnośredniowiecznych kurhanów na południu Polski, dla których zawartość fosforu mieści się w granicach $0,04-0,12 \% \mathrm{P}$, ze średnią arytmetyczną wynoszącą około $0,072 \%$ P. Taki stan technologiczny rejonu Małopolski w wytwórczości „żelaza” wynikał, jak się wydaje, $\mathrm{z}$ odmiennych tradycji $\mathrm{w}$ tym zakresie, na który decydujący wpływ miały dość ścisłe jeszcze wówczas związki Małopolski z państwem wielkomorawskim. Ta „nowa” (skandynawska) technika wytwarzania przedmiotów żelaznych zdaje się nie dotarła w tym czasie jeszcze do Krakowa i kraju Wiślan, a pojawia się tam wraz z panowaniem Bolesława Chrobrego i jego następców. Znaleziony w Krakowie skarb grzywny, czy też pręty „siekieropodobne” odkryte w Zawadzie Lanckorońskiej, Nowej Hucie czy Stradowie - są zapewne skarbami „wielkomorawskimi” (Piaskowski 1991, s. 82), choć w tym czasie należy też odróżniać tzw. metal „krakowski”, który mimo protekcji państwa wielkomorawskiego różni się od niego i stanowi własną, miejscową produkcję .

Szczególnie duże podobieństwo technologii, jaką stwierdzono w zbadanych nożach z Sowinek wykazały przedmioty żelazne z cmentarzyska w Lutomiersku koło Łaska, datowanego około połowy XI wieku, gdzie wystąpiła szczególnie duża ilość przedmiotów zgrzewanych z żelaza i stali (Piaskowski 1959c, s. 110-129). Wśród dziewięciu zbadanych tam noży technologię tę reprezentuje aż osiem noży $(88,9 \%)$, z czego sześć okazów to noże dwuwarstwowe (typu IV.2.A.1 wg klasyfikacji J. Piaskowskiego), równie często występujące w Sowinkach (Piaskowski 1959c, s. 121-124). Ponadto technologia zgrzewania żelaza i stali wystąpiła na tamtym 
$151 / f$

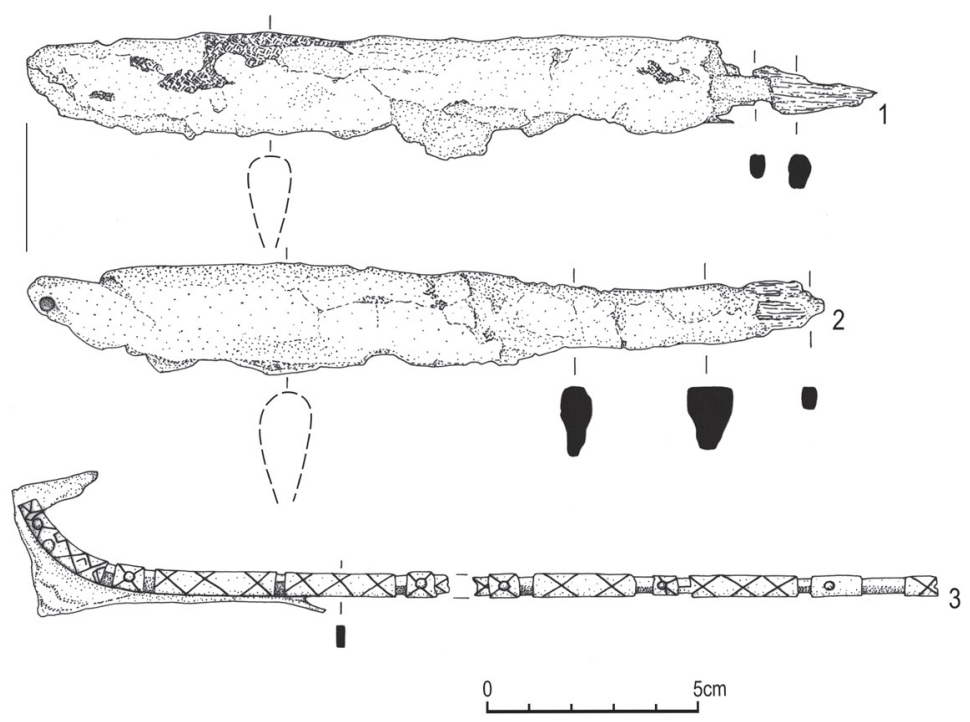

Ryc. 12. Noże żelazne typu If wg R. Rogosza (1983) (1-3) z brązowym okuciem skórzanej pochewki z grobu komorowego nr 151 (1 - nóż nr 1, 2 - nóż nr 2, 3 - brązowe okucie wspólnej skórzanej pochewki). Rys. Wiktor Kudra i Jolenta Kędelska, oprac. komp. Jolenta Kędelska

cmentarzysku w dwóch spośród trzech zbadanych mieczy, dwóch krzesiwach dwukabłąkowych, jednym toporze i w 10 spośród 12 zbadanych grotów włóczni (Piaskowski 1959c, s. 114-121, 125-129). Pośród tych ostatnich zabytków dwa z grotów miały na powierzchni nawet warstewki „damasceńskie” (tzw. „pattern -welding"). Takie sposoby wykonywania grotów włóczni występują też pospolicie w krajach bałtyjskich (Antejn 1973, s. 64 i n.) i można je uważać za broń Wikingów lub - być może - wykonywane były przez miejscowych kowali na wzór technologii „wikińskiej”. Stąd możliwe jest, że na cmentarzysku w Lutomiersku zostali pochowani wojownicy z drużyny Wikingów; ostatnie interpretacje odnośnie do pochowanych na tym cmentarzysku osób („drużynników”) uprawdopodobniają powyższe sugestie (por. ostatnio Grygiel 2014, s. 696-703). Zbliżona technologia wystąpiła również wśród wyrobów żelaznych z pobliskiego cmentarzyska w Buczku koło Łaska (z połowy XI w.), gdzie jeden z dwóch zbadanych noży był zgrzewany z pręta żelaznego i stalowego (w typie IV.1.A.1 wg klasyfikacji J. Piaskowskiego), a technika zgrzewania została zastosowana przy wyrobie obu zbadanych grotów włóczni (Piaskowski 1959a, s. 92). Należy dodać, że wśród pozostałych 11 zbadanych grotów włóczni z 11 innych wczesnośredniowiecznych stanowisk archeologicznych na ziemiach polskich technologia zgrzewania (w tym także cementacji) nie występuje. 
$70 / 1$
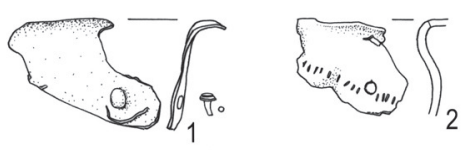

165/la
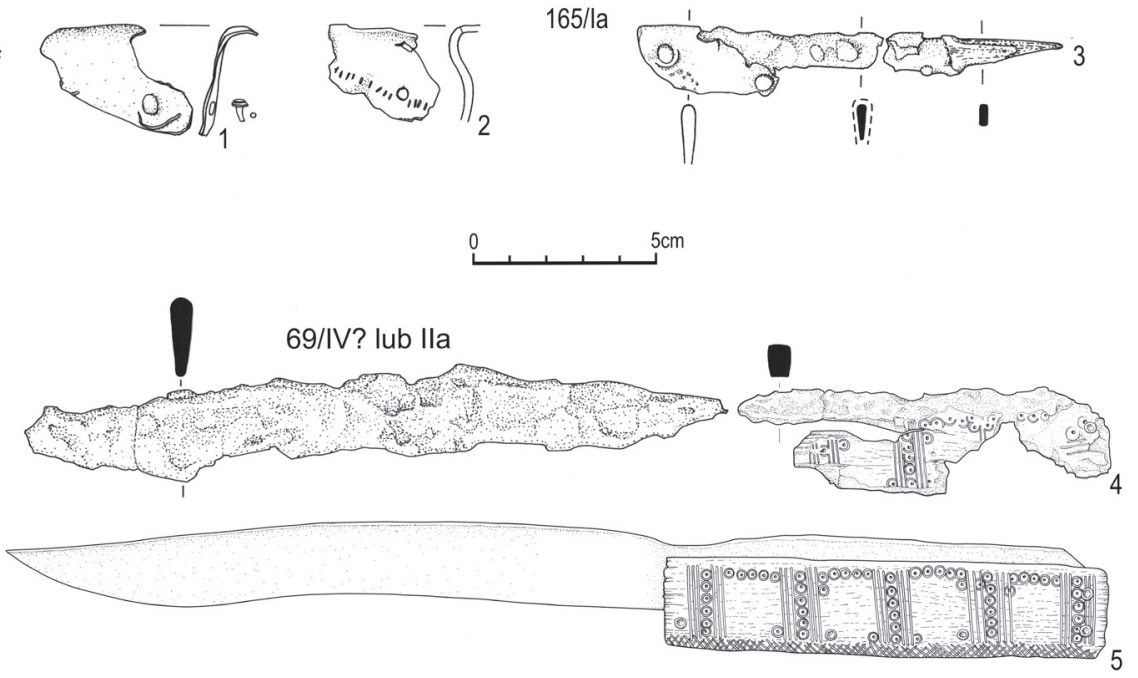

Ryc. 13. Noże żelazne typu Ia (3), typu IV lub IIa (4) wg R. Rogosza (1983) z grobów nr: 165 (3) i 69 (4), jego rekonstrukcją (5) oraz fragment brązowego okucia (1) i fragment skórzanej pochewki (2) od noża z grobu nr 70, z noża nr 1. Rys. Wiktor Kudra i Jolenta Kędelska, oprac. komp. Jolenta Kędelska

Wracając do wyników ekspertyzy noży z Sowinek, można stwierdzić, iż noże z prostą nakładką stalową (typu IV.1.A.1. wg J. Piaskowskiego), taką, jaką wykazały noże z grobów nr 16, 44 i 166 (w tabeli 2, poz. 1,3 i 9), pojawiły się na ziemiach północnej i środkowej Polski już w VI-VIII w. w osadzie w Szeligach koło Płocka (Piaskowski 1967, s. 36 i n.) ${ }^{4}$ i później - na kolejnych stanowiskach: w Łazach koło Kielc z VI-VIII w. (Piaskowski 1966a, s. 375-386), Kołobrzegu z IX-XI w. (Losiński 1959, s. 30-32; Piaskowski 1959b, s. 48-54; 1974, tabela 3), Młodzikowie z X-XII w. (Głowacki, Łosiński 1960, s. 166-176), Gdańsku z X-XI w. (Piaskowski 1960, s. 47-53, 75-83; 1974a, tabela 3). Od połowy XI w. technologia wykonywania noży z żelaza wysokofosforowego z prostą nakładką stalową, stanowiącą ostrze, obrabiane cieplnie (typu IV.1.A.1. wg J. Piaskowskiego, tak jak noże z grobów nr 16 i 44 z Sowinek) zdecydowanie wypierała inne sposoby wykonywania noży i występowała we wszystkich zbadanych wczesnośredniowiecznych stanowiskach, zarówno osadach, jak i cmentarzyskach.

\footnotetext{
${ }^{4}$ W tym wypadku wydaje się nam, iż konieczna jest rewizja chronologii noża odkrytego w jednej z jam na osadzie w Szeligach, która jest faktycznie późniejsza („młodsza”), aniżeli funkcjonuje to w literaturze przedmiotu (W. Szymański 1967), albowiem nóż ten wystąpił prawdopodobnie w sperturbowanej partii stropowej obiektu (por. też. W. Łosiński 1995).
} 


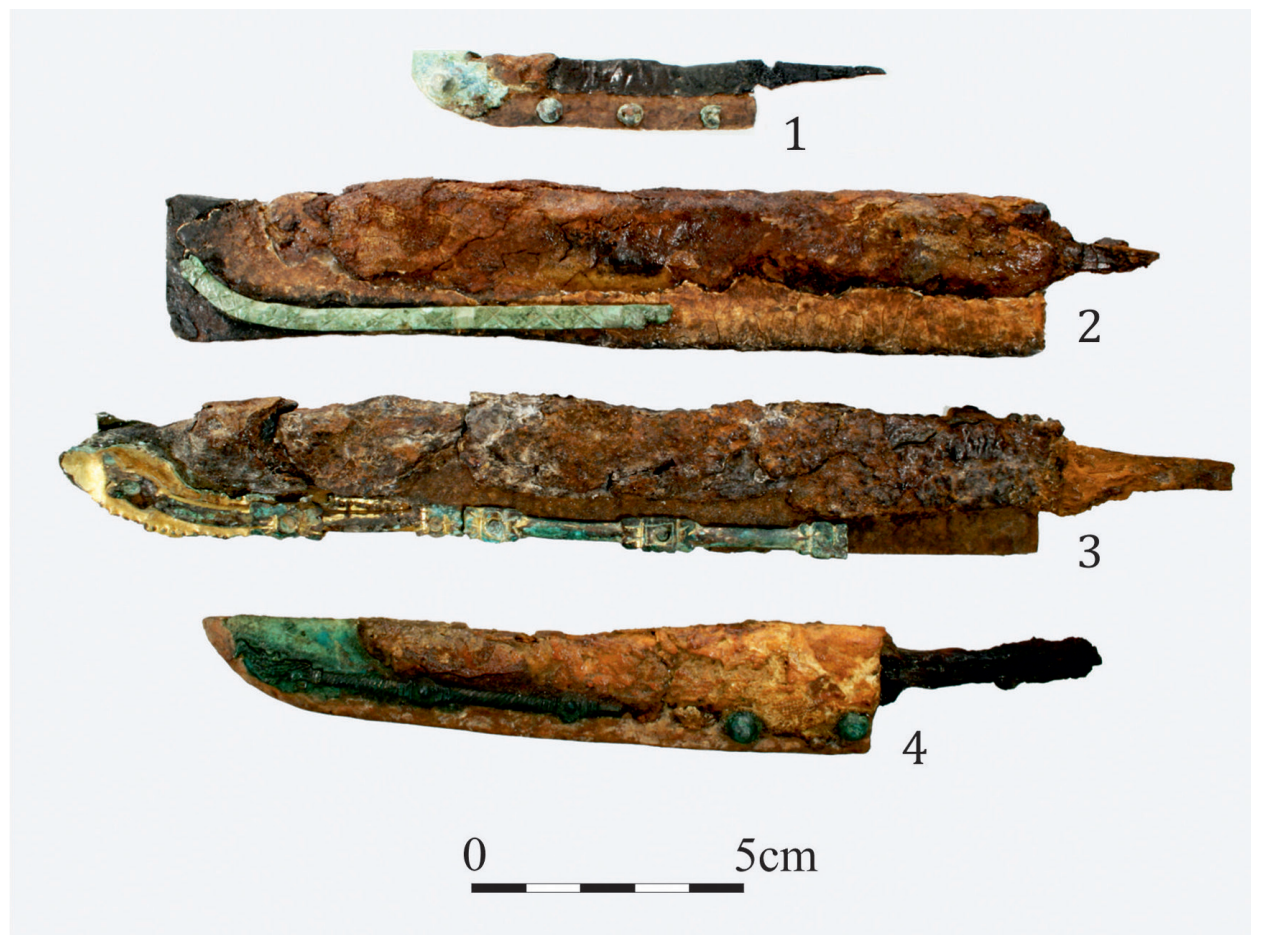

Ryc. 14. Noże żelazne typu Ia $(1,4)$ i typu If (2-3) wg R. Rogosza (1983) z grobów nr: 165 (1), 151 (2), 148 (3) i 176 (4). Fot. Klaudyna Kucharska, oprac. komp. Barbara Bednarczyk

Natomiast dwie dalsze techniki wykonywania noży zidentyfikowane w Sowinkach występowały na ziemiach polskich rzadziej i tylko przez krótki okres. I tak noże trójwarstwowe, jak np. nóż z grobu nr 61 wykonany techniką klasycznego „sandwich” (w tabeli 2, poz. 4) z Sowinek (typu IV.2.B.2 wg J. Piaskowskiego), pojawiły się zaraz po okresie wędrówek ludów, także wśród zbadanych noży z Biskupina z VI-XII w. (Piaskowski 1974a, tabela 3), Czeladzi Wielkiej z VII-VIII w. (Piaskowski 1966b, s. 150-175; 1974, tabela 3), Kołobrzegu z IX-X w. (Łosiński 1959, s. 30-32; Piaskowski 1959b, s. 48-54; 1974, tabela 3), Gdańska z XI w. (Piaskowski 1960, s. 47-53, 75-83; 1974a, tabela 3) i Poznania z XI w. (Głowacki 1961, s. 98, ryc. 68cd).

Podobnie trójwarstwowe noże z wkładką stalową niedochodzącą do grzbietu w zbliżonej do klasycznej technologii typu ,sandwich” (typu IV.2B.1 wg J. Piaskowskiego) - jak nóż z grobu nr 70 z Sowinek (w tabeli 2, poz. 6) - występowały sporadycznie, w pojedynczych egzemplarzach, m.in. na stanowiskach w Czeladzi Wielkiej na Śląsku (z VII-VIII w.) i w Gdańsku, stan. 2 (z XII-XIV w.), a kolejne dwa takie noże znaleziono na wzgórzu wawelskim w Krakowie z X-XI i XII w. (Piaskowski 1991, s. 62 i n., ryc. 4a, 7a). 

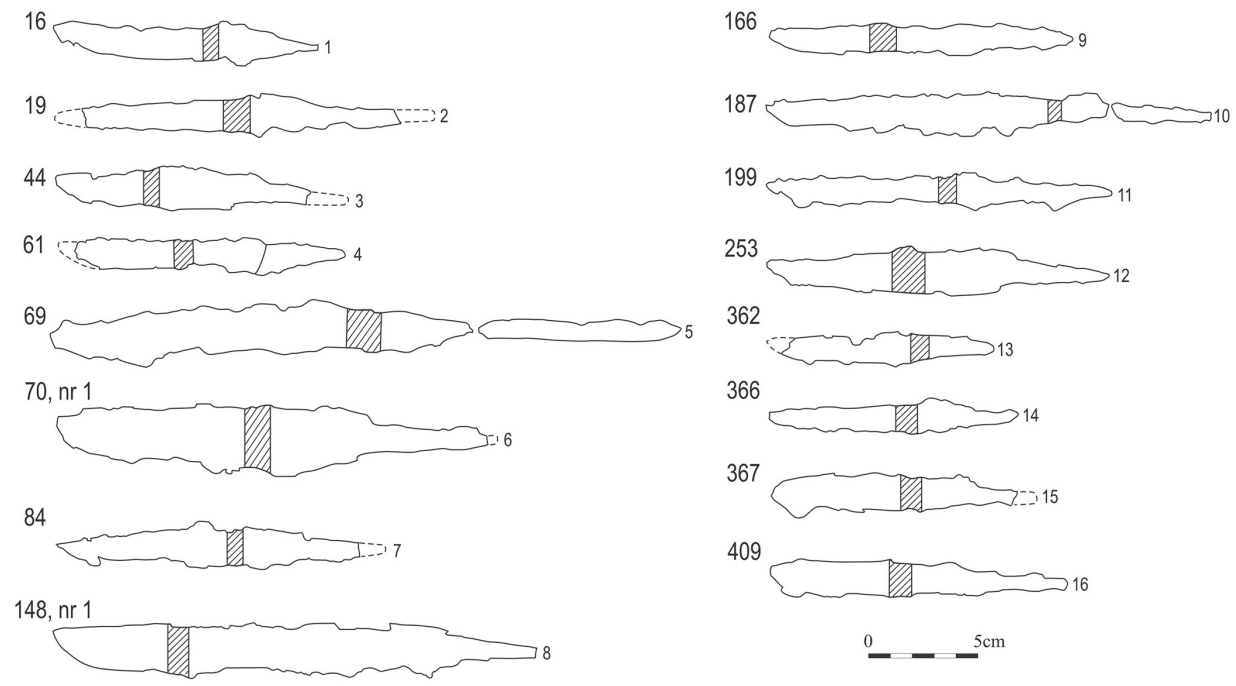

Ryc. 15. Schematyczne przedstawienie miejsca pobranych próbek z noży żelaznych poddanych analizie metalograficznej w Instytucie Odlewnictwa w Krakowie z grobów nr: 16 (1), 19 (2), 44 (3), 69 (4), 70, nóż nr 1 (6), 84 (7), 148, nóż nr 1 (8), 166 (9), 187 (10), 199 (11), 253 (12), 362 (13), 366 (14), 367 (15) i 409 (16). Rys. i oprac. komp. Barbara Bednarczyk

Później, po XI-XII w., oba te ostatnio opisane typy technologiczne zanikają. Te sposoby dawały wprawdzie narzędzia wyższej jakości, lecz były znacznie trudniejsze do wykonania niż noże wykonane $\mathrm{w}$ technologii z prostą nakładką stalową (typu IV.1.A.1. wg J. Piaskowskiego).

Występująca najliczniej wśród noży z Sowinek (w 8 nożach, tj. w 50\% zbadanych okazów) technologia zgrzewania żelaza i stali pojawiła się - jak wyżej zaznaczyliśmy - na ziemiach północnej i środkowej Polski zaraz po okresie wędrówek ludów i z czasem rozpowszechniła się coraz bardziej. W okresie od VI do X w. udział noży zgrzewanych z żelaza i stali wynosił średnio około $20 \%$, natomiast $\mathrm{w}$ okresie od XI do XII w. zwiększył się do niespełna $50 \%$ - poza tym słowiańscy kowale wykonywali te narzędzia $\mathrm{z}$ żelaza (prawdopodobnie niekiedy utwardzali je przez cementację) lub ze stali wysokofosforowej (Piaskowski 1971, s. $1-29 ; 1999$, s. 242).

W okresie od IX do XIII w. średni udział noży zgrzewanych z żelaza i stali zwiększył się do ponad 68,2\% (wg danych Piaskowski e g o 1985, s. 231 i n.). Równocześnie kowale słowiańscy stosowali proces zgrzewania żelaza i stali przy wyrobie także innych narzędzi tnących, jak sierpy, kosy, siekiery, dłuta, jednak rzadziej niż przy wyrobie noży (J. Piaskowski 1985, s. 231 i n.). Prawdopodobnie około X/XI w. technologia zgrzewania żelaza i stali rozpowszechniła się także na 

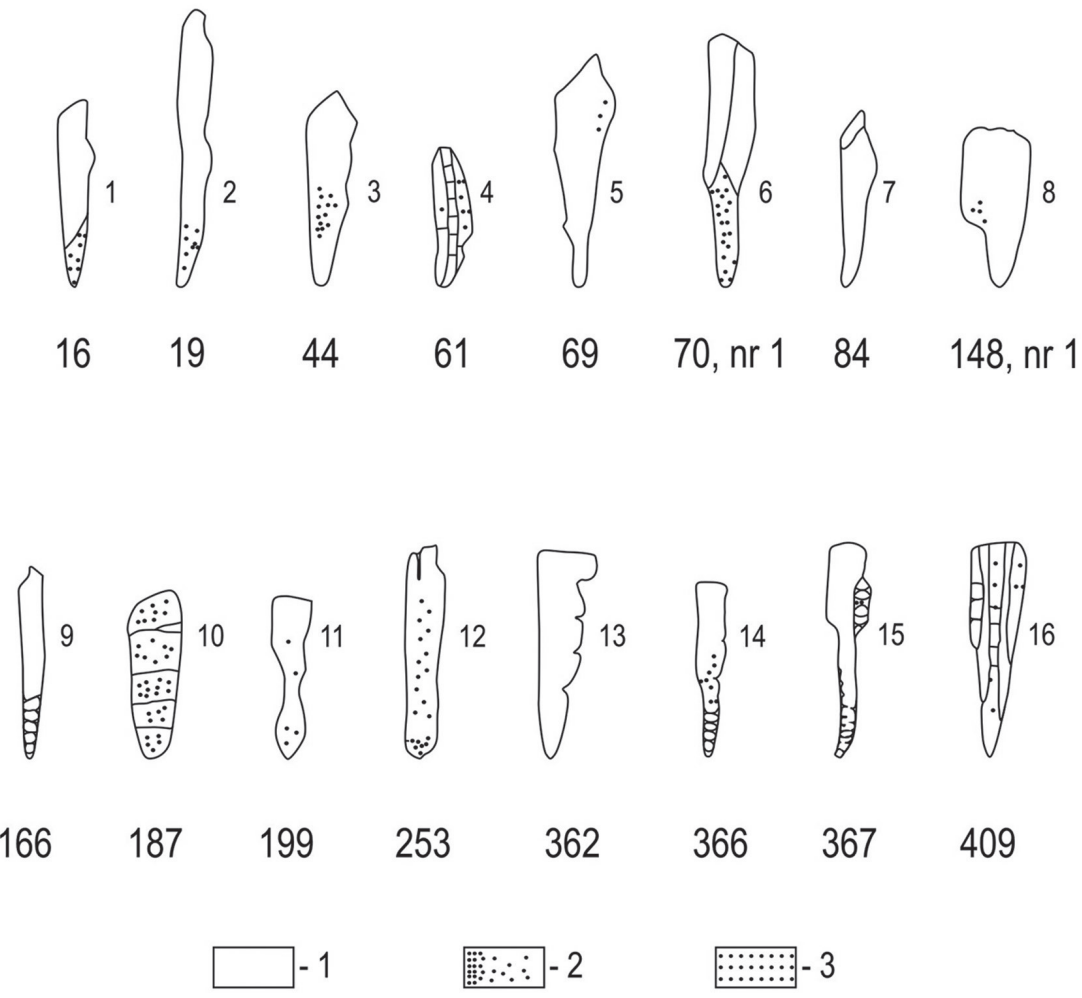

Ryc. 16. Technologia zbadanych noży żelaznych poddanych analizie metalograficznej w Instytucie Odlewnictwa w Krakowie z grobów nr: 16 (1), 19 (2), 44 (3), 69 (4), 70, nóż nr 1 (6), 84 (7), 148, nóż nr 1 (8), 166 (9), 187 (10), 199 (11), 253 (12), 362 (13), 366 (14), 367 (15) i 409 (16) (wg J. Piaskowskiego 1999, ryc. 2) (1 - żelazo, 2- żelazo nawęglone, 3 - stal). Rys. i oprac. komp. Barbara Bednarczyk

ziemiach południowej Polski, być może jako wynik zaanektowania istniejącego tam państwa Wiślan do królestwa Piastów.

$\mathrm{Na}$ innych, sąsiednich terenach opisana technologia zgrzewania żelaza i stali obserwowana przy wyrobie noży, podobnie jak na ziemiach Polski, pojawiła się również po okresie wędrówek ludów, choć liczba noży w tej technologii np. na terenie północno-wschodnich Niemiec była w okresie VI-X w. jeszcze niewielka ${ }^{5}$. Wyjątkiem w tym względzie jest osada w Ralswieck na Rugii (informacja uzyskana od prof. J. Piaskowskiego), gdzie pośród poddanych ekspertyzie 20 noży ziden-

5 Mam tu na uwadze dane z ekspertyz noży z osad w Dessau-Mosigkau, Kr. Luckau (wyniki na podstawie badań Pleinera 1967, s. 175-189, Taf. 9-20), w Tornow, Kr. Calau (wyniki na podstawie badań J. Piaskowskiego (1973, s. 311-334, Taf. 23, 24c-h, 25ab,g, 28e-h, 29a-f, 30d-h, 31a-f) i Presenchen, Kr. Luckau (wyniki na podstawie badań J. Piaskowskiego, informacja ustna od autora). 
tyfikowano tam osiem okazów o budowie trójwarstwowej (około 40\% pośród zbadanych), z czego sześć reprezentowało klasyczną technologię typu „sandwich” (typ IV.2.B.2 wg J. Piaskowskiego), a dwa noże posiadały wkładkę stalową niedochodzącą do grzbietu, tj. były zbudowane $\mathrm{w}$ technologii zbliżonej do wariantu „sandwich” (typ IV.2.B.1 wg J. Piaskowskiego). Podobne do opisanych wyżej zmiany technologii wykonania narzędzi tnących wystąpiły także w krajach bałtyckich, na Litwie, Łotwie i w Estonii. Na Litwie udział noży wykonanych w technologii zbliżonej do „sandwich”, tj. z wkładką stalową niedochodzącą do grzbietu (typ IV.2.B.2 wg J. Piaskowskiego), wynoszący w okresie V-VIII w. - 6,3\%, zwiększył się w okresie IX-XIII w. - do 26,8\% (Stankus 1970a, s. 113-132; 1970b, s. 57-74).

Podobnie rozpowszechniła się technologia zgrzewania żelaza i stali na terenie Rusi Kijowskiej, gdzie w okresie IX-XIII w. (Kolčin 1953, s. 53) średni udział technologii w rodzaju „sandwich” (typ IV.2.B.2 wg J. Piaskowskiego) wynosił około 17\% ogółu badanych noży (przy 32\% okazów w postaci stalowej nakładki zgrzanej z żelaznym korpusem narzędzia i aż 55\% wszystkich okazów zgrzewanych z żelaza i stali). Powyższe odsetki noży zgrzewanych z żelaza i stali spotyka się najczęściej w kolekcjach pochodzących z północnych połaci ziem ruskich (wykonane techniką ,sandwich" z centralnie umieszczoną wkładką stalową stanowią tu aż około $25 \%$ ogółu zbadanych noży), podczas gdy w materiałach pochodzących z południowej Rusi odsetek okazów noży wykonanych w technice trójwarstwowej wynosi zaledwie 5\% (Łosiński $1995 \mathrm{~s}, 24 \mathrm{i}$ n.). Te zmiany technologiczne można szczególnie dokładnie zaobserwować dzięki przeprowadzonym badaniom archeologicznym w Nowgorodzie, gdzie zidentyfikowano 28 poziomów osadniczych od X do XV w., z przebadaną kolekcją liczącą aż 540 egzemplarzy noży (Kolčin 1959, s. 7n.; Kolčin, Janin 1982, s, 119). Noże trój- (klasyczny typ „sandwich”, typ IV.2.B.2 wg J. Piaskowskiego) i pięciowarstwowe (typ IV.3.C.1 wg J. Piaskowskiego) były stosowane tam już w latach 940-960, po czym te pierwsze zanikły około 1130 roku, te drugie zaś nieco wcześniej, bo już około 1090 roku. Następnie na krótki okres od 1100 do 1140 była stosowana technologia zgrzewania z wkładką stalową niedochodzącą do grzbietu (zbliżoną do typu „sandwich", typu IV.2.B.1 wg J. Piaskowskiego), ale i ona utrzymała się tylko około 50 lat. Natomiast noże dwuwarstwowe z prostą nakładką stalową (typ IV.1.A.1 wg J. Piaskowskiego), które pojawiły się około 1110 r. z czasem stały się najczęstszym sposobem wykonywania noży, podobnie jak i na ziemiach Polski (Kolčin 1959, s. 52 i n.; 1982, s. 164, ryc. 4; Kolčin, Janin 1982, s, 120; Łosiński 1995, s. 33-36). Podobne rezultaty osiągnięto $w$ wyniku badań noży także $w$ innych ośrodkach państwa ruskiego, m.in. w Starej Ładodze, gdzie w produkcji noży powszechnie stosowano technikę typu „sandwich”, począwszy już od połowy VIII wieku (Chomutowa 1984, s. 208; Rjabinin 1994, s. 39 n.).

Technologia ta niewątpliwie została rozpowszechniona ze Skandynawii przez Wikingów (Waregów). Już pochodzące z VII w. miecze ze znanych znalezisk 
w Vendel i Valsgårde w Szwecji miały na powierzchni dobrze wykonany wzór „damasceński” czy podobnie jak grot włóczni pochodzący z Gotlandii z VIII w. (Thålin-Bergman 1983, s. 157). Istnieją jednak podstawy do hipotezy, że technika zgrzewania, a nawet zdobienia wzorem „damasceńskim” (tzw. „pattern-welding”) została opanowana w Szwecji już II-I w. p.n.e. lub nawet wcześniej (Thålin-Bergman 1979, s. 120 i n.).

Analizy metaloznawcze 12 badanych noży z osady i cmentarzyska w Birce położonych we wschodniej części jeziora Mälaren wykazały powszechne stosowanie technologii zgrzewania żelaza i stali aż w 90\% kolekcji, przy czym w przypadku siedmiu noży wystąpiła tam technika typu „sandwich” (Arrhenius 1989, s. 79 i n.). Technikę tę stwierdzono również $w$ jednym $z$ dwóch badanych noży z wyspy Helgö u ujścia jeziora Mälaren, w środkowej Szwecji, w miejscu zgrzania zaobserwowano tu bardzo cienką warstewkę, prawdopodobnie z żelaza arsenowego (Modin, Plainer 1978, s. 81-109, nóż nr 11355). Występowanie takich wkładek $\mathrm{z}$ żelaza arsenowego, prawdopodobnie zawierającego około $1 \%$ As, przy zgrzewaniu żelaza i stali stwierdzono także $\mathrm{w}$ innych wyrobach żelaznych z południowej Szwecji. Miał to być sposób w obróbce przedmiotów żelaznych stosowany przez Wikingów, chociaż należy też zaznaczyć, iż równolegle stosowano tu i inne techniki zgrzewania $\mathrm{w}$ postaci okazów z ostrzami stalowymi w postaci klinowatych wkładek lub nakładek zgrzanych z żelaznym korpusem narzędzia (Tomtlund 1973, noże nr 1 i 10; Thomsen 1994, s. 281 i n.).

$\mathrm{Z}$ wielu powodów nie jesteśmy w stanie jednoznacznie ocenić, jakie było technologiczne oddziaływanie Wikingów na terenie północno-zachodniej Europy w zakresie wykonywania przedmiotów żelaznych, czy i tam wprowadzili swoje metody, czy też może sami te metody przejęli. Zauważmy, że występują tam także pewne podobieństwa do technologii znanej wcześniej $\mathrm{w}$ broni $\mathrm{z}$ okresu merowińskiego i wczesnokarolińskiego, będącej z kolei niewątpliwą spuścizną techniki kowalstwa prowincjalnorzymskiego (Salin 1957, s. 27; Piaskowski 1974a, s. 93; 1974b, s. 65; Łosiński 1995, s. 46 i przypis 1). Najprawdopodobniej ten ostatni „frankoński” (a kolejno „saski”) kierunek odegrał w rozprzestrzenieniu „,nowej” technologii zgrzewania żelaza i stali decydującą rolę, i zgodnie sądzi się, że technika ta osiągnęła wówczas najwyższy poziom rozwoju. Kolejno technologia ta została niewątpliwie przez Wikingów wprowadzona, rozwinięta i upowszechniona w krajach wschodniej Europy (Chomutova 1984, s. 208; Rjabinin 1994, s. 43; Rozanova 1997, s. 212 i n.; Łosiński 1995, s. 46-48 i przypis 1; 2000, s. 499).

Podsumowując zagadnienia technik kowalskich, można stwierdzić, iż z zaprezentowanej ekspertyzy noży z Sowinek wynika, że noże z tego cmentarzyska reprezentują (wg J. Piaskowskiego, autora tej ekspertyzy) - typ metalu i technologie charakterystyczne dla dorzecza Wisły, a także dla wczesnośredniowiecznej Rusi Kijowskiej (Kolčin 1953, s. 5-258). Ze względu na zarejestrowaną w Sowinkach różnorodność typów technologicznych fakt ten z danymi chronologicznymi ich występowania w przytoczonych sąsiedzkich Wielkopolsce rejonach - pozwala je 
datować na okres X-XII wieku. Niewątpliwie wytop żelaza i stali - na podstawie ekspertyzy noży z Sowinek - następował tutaj z wysokofosforowych miejscowych rud darniowych i bagiennych, który rozpowszechnił się na ziemiach polskich w zasadzie około VI w., po okresie wędrówek ludów. Pojawiła się wtedy technologia zgrzewania żelaza ze stalą wraz z obróbką cieplną, w tym charakterystyczna dla tego okresu technologia typu „sandwich”, którą w klasycznej trójwarstwowej (wertykalnej) wersji stwierdzono również w wykonaniu dwóch noży z Sowinek, z grobów nr 61 i 409.

Na zmiany technologiczne w tym zakresie niewątpliwie istotny wpływ mieli skandynawscy Wikingowie. Ich technologiczne oddziaływanie łączyło się, oczywiście, przede wszystkim z ekspansją gospodarczą, ale i może polityczną, czego pośrednim dowodem na terenie Polski są wczesnośredniowieczne cmentarzyska w Ciepłem, w pow. Pruszcz Gdański (Ratajczyk 2011, s. 553 i n.; 2013, s. 323 i n.), w Lutomiersku, w pow. łaskim (Jażdżewski 1949, s. 158-159; Nadolski, Abramowicz, Poklewski 1959, s. 149; Kurnatowska 2002, s. 202-203; Grygiel 2014, 696-703) czy ostatnio w Bodzi, w pow. włocławskim (Kara 2013, s. 117 i n.; 2016, s. 481 i n.; Müller-Wille 2016, s. 459 i n.), gdzie pochowano niewątpliwie „drużynników” rusko-wareskich. Zdaniem W. Łosińskiego (1995, s. 46-48; 2000, s. 498) - noże wykonane w technice zgrzewania żelaza i stali, a szczególnie te wykonane w wariancie „sandwich”, należały w tym okresie do przedmiotów szczególnie chętnie nabywanych, stąd znajdowały one powszechny zbyt nie tylko w nowo powstających ośrodkach rzemieślniczo-wczesnomiejskich pobrzeża bałtyckiego, ale i również na terenach wspólnot lokalnych w głębi interioru Słowiańszczyzny zachodniej i wschodniej.

\section{LITERATURA}

Andrzejewska A. 1996, Średniowieczny zespół osadniczy w Zgłowiączce na Kujawach, Włocławek. Antejn A.K. 1973, Damasskaja stal'v stranach bassejna Baltijskogo morja, Riga.

Arbman H. 1940-1943, Birka I: die Gräber. Tafeln-Text, Uppsala.

Arrhenius B. 1989, Arbeitsmesser aus den Gräbern von Birka. Mit einem Appendix, Birka II:3. Systematische Analalysen der Gräberfunde, Stockholm, s. 79-92.

Arne T.J. 1931, Skandinawische Holzkammergraber aus der Wikingerzeit in der Ukraine, ,Acta Archaeologica" 2, København, s. 285-302.

Chomutova L.S. 1984, Kuznečnaja technika na zemle drevniej vesi v X v. (po materialam poselenija u d. Gorodišče), „Sovietskaja archeologia”, t. 1, s. 199-209.

Chudziak W. 2001, Wczesnośredniowieczne groby komorowe z Katdusa pod Chetmnem na Pomorzu Wschodnim, „Slavia Antiqua”, t. 42, s. 63-96.

- 2002, Ślady skandynawskiej obrzędowości w Kałdusie na Pomorzu Wschodnim, w: Popiół i kość, „Funeralia Lednickie”, t. 4, red. J. Wrzesiński, Sobótka-Wrocław, s. 433-449.

- 2006, Problem projekcji mitu kosmologicznego na organizacje przestrzeni sakralnej in Culmine na Pomorzu Nadwiślańskim, „Slavia Antiqua”, t. 47, s. 67-97.

Chudziak W., Bojarski J., Stawska V. 2010, Wyposażenie pochówków, w: W. Chudziak (red.) Wczesnośredniowieczne cmentarzysko szkieletowe w Kałdusie (stanowisko 4), Mons Santi Laurenti, t. 5, Toruń, s. 79-103. 
Gabriel I. 1988, Hof- und Sakralkultur sowie Gebrauchs- und Handelsgut im Spiegel der Kleinfunde von Starigard Oldenburg, w: Oldenburg-Wolin-Staraja Ladoga-Novgorod-Kiev. Handel und Handelsverbindungen im südlichen Ostseeraum während des frühen Mittelalters, BdRGK, t. 69, s. 103-191.

Glyn D. 1981, A Short History of Archaeology (Ancient Peoples and Places), London.

Głowacki Z. 1961, Uwagi na temat technologii wykonania zabytków metalowych z XI-XIII w. z Ostrowa Tumskiego w Poznaniu (1953-1954), w: W. Hensel (red.), Poznań we wczesnym średniowieczu, t. 3, Wrocław-Warszawa, s. 95-105.

Głowacki Z., Łosiński W. 1960, Badania metaloznawcze noży z wczesnośredniowiecznego cmentarzyska w Młodzikowie, pow. Środa, FAP, t. 11, s. 166-178.

Grygiel R. 2014, Cmentarzysko wareskich drużnników w Lutomiersku, w: R. Grygiel, T. Jurek (red.), Poczatki Łęczycy, t. 2. Archeologia o początkach Łęczycy, Łódź, s. 681-751.

Gurin M.F. 1987, Kuznečnoe remeslo Polockoj zemli IX-XIII vv., Minsk.

Hołowińska Z. 1959, Wczesnośredniowieczne rzemiosło złotnicze w Gdańsku, w: J. Kamińska (red.), Gdańsk wczesnośredniowieczny, t. 1, Gdańsk, s. 55-105.

Hołubowicz W. 1956, Opole w wiekach X-XII, Katowice.

Jagodziński M. 2010,Truso między Weonodlandem a Witlandem, Elbląg.

Jażdżewski K. 1949, Cmentarzysko wczesnośredniowieczne w Lutomiersku pod Łodzia w świetle badań z r. 1949, „Materiały Wczesnośredniowieczne”, t. 1, s. 91-191.

Kaszewscy E. i Z. 1971, Wczesnośredniowieczne cmentarzysko w Brześciu Kujawskim, pow. Włocławek, „Materiały Starożytne i Wczesnośredniowieczne”, t. 1, s. 365-432.

Kara M. 2013, Wybrane groby z uzbrojeniem z cmentarzyska w Bodzi pod Włoctawkiem - przyczynek do studiów nad obecnościa ,, wikingów” w państwie pierwszych Piastów, w: T. Sawicki (red.), Studia nad dawną Polską, t. 3, Gniezno, s. 117-131.

- 2016, Cmentarzysko w Bodzi w kontekśsie praktyk funeralnych ludności ziem polskich 2. połowy $X-X I$ w., w: A. Buko (red.), Bodzia. Elitarny cmentarz z początków państwa polskiego, Warszawa, s. 481-486.

Knorr H.A. 1938, Die slawischen Messerscheidenbeschläge, „Mannus“, t. 30, Heft 4, s. 479-545.

Kolčin B.A. 1953, Čornaja metallurgija i metallobrabotka v drewniej Rusi, „Materialy i Issledovanija po Archeologii SSSR", No 32, s. 5-258.

- 1959, Zeliezoobrabatyvajusceje riemieslo Novgoroda Velikogo. Trudy Novgorodskoj Arheologiceskoj Ekspedicji, t. 2, „Materialy i Issledovanija po Archeologii SSSR”, No 65, s. 7-120.

- 1982, Chronologija novgorodskich drevnostej, w: Tezisy dokladov Sovetskoj delegacii na III Meždunarodnyj Kongress Slavjanskoj Archeologii, Mockva, s. 53-58.

Kolčin B.A., Janin V.L. 1982, Archeologii Novgoroda 50 let, w: Novgorodskij sbornik. 50 let raskopok Novgoroda, Mockva, s. 3-136.

Koperkiewicz A. 2005, Wczesnośredniowioeczne dary grobowe w kontekście symboliki chrześcijańskiej, w: Do, ut des - dary, pochówek, tradycja, „Funeralia Lednickie” 7, red. W. Dzieduszycki, J. Wrzesiński, Poznań, s. 269-291.

Kozak J. 1996, Wczesnośredniowieczne cmentarzysko szkieletowe w Sowinkach (gm. Mosina, woj. poznańskie): analiza antropologiczna i paleodemograficzna, „Przegląd Antropologiczny” 59, s. 91-96.

Krzyszowski A. 1992, Wstępne wyniki badań archeologicznych na wczesnośredniowiecznym cmentarzysku szkieletowym z X/XI-XI wieku w miejscowości Sowinki, gm. Mosina, woj. poznańskie, stanowisko 23A, WSA, t. 1, s. 83-102.

- 1995, Ein reiches Gräberfeld aus dem 10./11.Jh. in Sowinki bei Poznań, „Slavia Antiqua”, t. 36, s. $49-72$.

- 1997, Frühmittelalterliches Grab eines Kaufmannes aus Sowinki, Germania, Jahrb. 75, 2. Halband, s. 639-667.

Krzyszowski A., Błaszczyk D. 2016, Datowanie radiowęglowe grobów komorowych z wczesnośredniowiecznego cmentarzyska w Sowinkach (stan. 23a) w Wielkopolsce, FPP, t. 21, s. 213-234.

Krzyszowski A., Suchodolski S. 2018, Monety i przybory kupieckie z wczesnośredniowiecznego cmentarzyska w miejscowości Sowinki (powiat poznański), „Wiadomości Numizmatyczne”, R. 62, z. 1-2, s. $145-168$ 
Kurnatowska Z. 2002, Cmentarzysko w Lutomiersku, w: M. Derwich, A. Żurek (red.), „U źródeł Polski”, t., Do roku 1038, Polska. Dzieje cywilizacji i narodu, Warszawa-Wrocław, s. 202-203.

Leciejewicz L., Łosiński W. 1960, Wczesnośredniowieczne cmentarzysko w Młodzikowie, pow. Środa, FAP, t. 11, s. 104-165.

Lityńska-Zając M. 1994, Wyniki analizy drewien i węgli drzewnych z wczesnośredniowiecznego cmentarzyska szkieletowego z X/XI-XI wieku w miejscowości Sowinki, gm. Mosina, woj. Poznań, stanowisko 23A, Kraków (maszynopis).

Łęga W. 1930, Kultura Pomorza we wczesnym średniowieczu na podstawie wykopalisk, Toruń.

Łosiński W. 1959, Kowalstwo we wczesnośredniowiecznym Kołobrzegu. Z badań nad rzemiostem we wczesnośredniowiecznym Kołobrzegu, w: Prace Komisji Archeologicznej PTPN, t. 4, zeszyt 1/1-2, Poznań, s. 9-48.

- 1995, Rola rzemiosła skandynawskiego w dziejach gospodarczych wczesnośredniowiecznej Europy w świetle badań metaloznawczych noży żelaznych, Poznań-Szczecin (maszynopis udostępniony przez Autora).

- 2000, Miejsce rzemiosta $w$ dziejach handlu dalekosiężnego w krajach strefy nadbaltyckiej, w: A. Buko, P. Urbańczyk (red.), Archeologia w teorii i w praktyce, Warszawa, s. 493-506.

Malinowska-Łazarczyk H. 1982, Cmentarzysko wczesnośredniowieczne w Cedyni, t. 1-2, Szczecin.

Michalska D., Krzyszowski A. 2017, Chronology of milticultural Site Sowinki in Greater Poland, Geochronometria 44 (2017), s. 30-39.

Modin S., Pleiner R. 1978, The metallographic examinations of locks, keys and tools, w: Excavations at Helgö V:1, Stockholm, s. 81-109.

Müller-Wille M. 2016, Cmentarzysko w Bodzi w kontekście odkryć w pótnocno-zachodniej i wschodniej Europie, w: A. Buko (red.), Bodzia. Elitarny cmentarz z początków państwa polskiego, Warszawa, s. $459-480$.

Nadolski A., Abramowicz A., Poklewski T. 1959, Cmentarzysko z XI wieku w Lutomiersku pod Łodzia, „Acta Archaeologica Universitatis Lodziensis”, nr 7, Łódź.

Okulicz-Kozaryn Ł. 1993, Finowie Zachodni, Warszawa.

Piaskowski J. 1959a, Metaloznawcze badania wczesnośredniowiecznych wyrobów żelaznych na przykładzie zabytków archeologicznych z Łęczycy, Czerchowa i Buczka, „Studia z Dziejów Górnictwa i Hutnictwa", t. 3, s. 7-97.

- 1959b, Technologia wczesnośredniowiecznych noży z Kołobrzegu na podstawie badań powierzchniowych, $Z$ badań nad rzemiostem we wczesnośredniowiecznym Kołobrzegu, Prace Komisji Archeologicznej PTPN, t. 4, zeszyt 1/1-2, Poznań, s. 48-54.

- 1959c, Metaloznawcze badania wyrobów żelaznych, w: A. Nadolski, A. Abramowicz, T. Poklewski, Cmentarzysko z XI wieku w Lutomiersku pod Łodzia, Łódź, s. 110-139.

- 1960, Technika gdańskiego hutnictwa i kowalstwa żelaznego $w$ X-XIV wieku na podstawie badań metaloznawczych, Gdańskie Towarzystwo Naukowe, Prace Komisji Archeologicznej nr 2, Gdańsk wczesnośredniowieczny, t. 2, Gdańsk, s. 5-172.

- 1966a, Sprawozdanie z metaloznawczych badań przedmiotów żelaznych z wczesnośredniowiecznej osady w Eazach, pow. Kielce, Spr. Arch., t. 18, s. 375-386.

- 1966b, Metaloznawcze badania przedmiotów żelaznych z wczesnośredniowiecznej osady w Czeladzi Wielkiej, pow. Góra, „Slavia Antiqua”, t. 8, s. 150-175.

- 1967, Metaloznawcze badania przedmiotów żelaznych i żużla z Szelig i Cekowa, pow. Płock oraz Cieślina, pow. Sierpc, w: W. Szymański, Szeligi pod Płockiem na początku wczesnego średniowiecza. Zespót osadniczy z VI-VII w., Wrocław-Warszawa-Kraków, s. 363-396.

- 1971, Zagadnienie ciagłości rozwoju hutnictwa żelaza na ziemiach polskich $w$ starożytności $i$ we wczesnym średniowieczu, „Roczniki Dziejów Społecznych i Gospodarczych”, t. 32, s. 1-29.

- 1973, Die Eisentechnologie in Tornow auf Grund der metallkundlichen Analyse, [w:] J. Herrmann (red.), Die germanischen und slawischen Siedlungen und das mittelalterliche Dorf von Tornow, Kr. Calau, Berlin, s. 311-336.

- 1974a, Untersuchungen der früh-mittelalterlichen Eisen- und Stahltechnologie der Slawen in den Gebieten zwischen Wiechsel und Oder, APol., t. 15, s. 67-96.

- 1974b, O stali damasceńskiej, Wrocław-Warszawa-Kraków-Gdańsk. 
- 1985, Bemerkungen zu den Eisenhüttungszentren auf polnischen Gebiet in Ur- und Frühgeschtlicher Zeit, w: Produktivkräfte und Produktionsverhältnisse, Berlin, s. 231 i n.

- 1991, Technologia wczesnośredniowiecznych przedmiotów żelaznych ze wzgórza wawelskiego, „Studia Dziejów Wawelu", t. 5, s. 55-92.

- 1999, Metaloznawcze badania noży żelaznych z wczesnośredniowiecznego cmentarzyska $w$ Sowinkach, gm. Mosina, woj. poznańskie, FPP, t. 9, s. 231-243.

Piekalski J. 1991, Wrocław średniowieczny. Studium kompleksu osadniczego na Otbinie w VII-XIII w., Wrocław.

Pleiner R. 1967, Metallkundliche Untersuchungen der Messerklingen von der frühslavischen Siedlung in Dessau-Mossigkau, w: B. Krüger (red.), Dessau-Mosigkau. Ein frühslawischer Siedlungsplatz im mittleren Elbegebiet, Deutsche Akademie der Wissenschaften zu Berlin Schriften der Sektion für Vor- und Frühgeschichte, t. 22, s. 175-189.

Radek T. 1994, Wynik ekspertyzy fragmentów skór z wczesnośredniowiecznego cmentarzyska szkieletowego w miejscowości Sowinki, gm. Mosina, stanowisko 23A (X/XI-XI wiek), Wrocław (maszynopis).

Rajewski Z.A. 1937, Wielkopolskie cmentarzyska rzędowe okresu wczesnodziejowego, PA, t. 6, s. 28-85.

- 1939a, Zabytki z rogu i kości w grodzie gnieźnieńskim, [w:] J. Kostrzewski (red.), Gniezno w zaraniu dziejów (od VIII do XIII wieku) w świetle wykopalisk, Poznań, s. 66-102.

- 1939b, Gnieźnieńskie wyroby skórzane z okresu wczesnodziejowego, w: J. Kostrzewski (red.), Gniezno w zaraniu dziejów (od VIII do XIII wieku) w świetle wykopalisk, Poznań, s. 103-116.

Ratajczyk Z. 2011, Nowe odkrycia na cmentarzysku z okresu wczesnego średniowiecza w Cieplem, gm. Gniew, stanowisko 6, w: M. Fudziński, H. Paner (red.), XVII Sesja Pomorzoznawcza, t. 1. Od epoki kamienia do wczesnego średniowiecza, Gdańsk, s. 553-570.

- 2013, The cemetery in Cieple - current research results, w: S. Moździoch, P. Wiszewski (red.), Scandinavian Culture in Medieval Poland, Interdisciplinary Medieval studies, vol. 2, Wrocław, s. $323-351$.

Rauhut L. 1971, Wczesnośredniowieczne cmentarzyska w obudowie kamiennej na Mazowszu i Podlasiu, „Materiały Starożytne i Wczesnośredniowieczne”, t. 1, s. 435-653.

Rjabinin E. A. 1994, U istokov remeslennogo proizvodstva v Ladoge (k istorii obščebaltijskich svjazej v prodvikinskuju epochu), Novue istočniki po archeologii Severo-Zapada, Sankt-Peterburg, s. 5-59.

Rogosz R. 1983, Obróbka i zastosowanie żelaza, [w:] E. Cnotliwy, L. Leciejewicz, W. Łosiński (red.), Szczecin we wczesnym średniowieczu. Wzgórze Zamkowe, Wrocław-Warszawa-Kraków-Gdańsk -Łódź, s. 262-267.

Rozanova L. S. 1997, K voprosu o technologii izgotovlenija železnych izdelli v srednevwekovom Pskove (po materialam Dovmontova gorola), Pamjatniki stariny. Kocepcii-Otkrytija-Versii, t. 2, Sankt-Peterburg, s. 206-213.

Salin E. 1957, La civilisation mérovingienne, t. 3. Les techniques, Paris.

Stankus J. 1970a , Geleziniu ịrankiu gamybos technologija Lietuvoje IX-XIII amažias, Lietuvos TSR Mokslu akademijos darbai, A serija, t. 1 (32), Trudy Akademii nauk Litowskoj SSSR, Serija A, t. 1 (32), Wilnius, s. 113-133.

- 1970b, Geležies dirbiniu gamybos Lietuvoje V-VIII amžiais technologija, Lietuvos TSR Mokslu akademijos darbai, A serija, t. 3 (34), Trudy Akademii nauk Litowskoj SSSR, Serija A, t. 3 (34), Wilnius, s. 57-75.

Szymański W. 1967, Szeligi pod Płockiem na początku wczesnego średniowiecza. Zespót osadniczy z VI-VII w., Wrocław-Warszawa-Kraków.

Thålin-Bergman L. 1979, Blacksmithing in Prehistoric Sweden, w: Clarke H. (red.), Iron and Man in Prehistoric Sweden, Stockholm, s. 99-133.

- 1983, Techniques and Craftsmanship In the Vendel Periode, w: Vendel Periode Studies, Stockholm, s. $151-162$.

Thomsen R. 1994, Metallografiske undersøgelser af svaerd og spydspidser fra mosefundene i Illerup og Nydam, Aarbøger for Nordisk Oldkyndighed og Historie 1992, s. 281-310.

Tomtlund J.-E. 1973, Metallographic Investigation og 13 Knives from Helgö, "Antikvariskt Arkiv", vol. 50 , s. $42-63$.

Tõnisson E. 1974, Die Gauja-Liven und ihre materielle Kultur (11.Jh. - anfang 13.Jhs.). Ein Beitrag zur ostbaltischen Frühgeschichte, Tallinn. 
Tuszyński M. 2003, Spotkania z archeologia. Spotkanie I Grzybowo 1988-2003, Poznań.

Wachowski K. 1975, Cmentarzyska doby wczesnopiastowskiej na Ślasku, Wrocław-Warszawa-Kraków -Gdańsk.

Wiklak H. 1963, Gdańskie pochewki na noże z X-XIII wieku, w: J. Kamińska (red.), Gdańsk Wczesnośredniowieczny, t. 6, s. 67-81.

Wilson D. M., Klindt-Jensen O. 1966, Viking Art, London.

Winiecki A. 1994, Ekspertyza dotyczaca oznaczenia ptaka - elementu okucia pochewki noża żelaznego z obiektu 176 z wczesnośredniowiecznego cmentarzyska szkieletowego z X/XI-XI wieku w miejscowości Sowinki, gm. Mosina, woj. Poznań, stanowisko 23A, Poznań (maszynopis).

Wojtasik J. 1960, Wczesnośredniowieczne wyroby ze skóry znalezione na stanowisku 4 w Wolinie, MZachpom., t. 6, s. 159-208.

- 1968, Cmentarzysko wczesnośredniowieczne na wzgórzu „Młynówka” w Wolinie, Szczecin.

- 1970, Cmentarzysko wczesnośredniowieczne na wzgórzu „Młynówka” w Wolinie (Badania w 1969 r.), MZachpom., t. 16, s. 289-323.

Wrzesiński J. 2000, Noże żelazne w grobach na wczesnośredniowiecznym cmentarzysku w Dziekanowicach, SL, t. 6, s. 91-124.

Zoll-Adamikowa H. 1971, Wczesnośredniowieczne cmentarzyska szkieletowe Matopolski, cz. 2. Analiza, Wrocław-Warszawa-Kraków-Gdańsk.

- 1975, Wczesnośredniowieczne cmentarzyska szkieletowe Małopolski, cz. 1. Źródła, Wrocław-Warszawa-Kraków-Gdańsk. 